\title{
A NEW CONFEDERACY? DISUNIONISM IN THE FEDERAL COURTS
}

\author{
PAUL D. CARRINGTON ${ }^{\dagger}$
}

INTRODUCTION

Perhaps the United States District Court for the Eastern District of Texas is seceding and we ought summon the ghost of General Grant from his stately tonıb on Riverside Drive to suppress it. Or at least the ghost of David Culberson, a nineteenth century Congressnian fron 1 Eastern Texas $^{1}$ who had a notion about how to deal with unruly judges. The intrepid Eastern District of Texas armed, by the improvidence of Congress, with the Civil Justice Reform Act of 1990 (CJRA) ${ }^{2}$ has set its face against the Rules Enabling Act of $1934^{3}$ as reconfirmed by Congress in $1988,{ }^{4}$ the Fees Act of $1853,{ }^{5}$ the Rules of Decision Act of 1789,6 three primciples of constitutional law, and, of course, the Federal Rules of Civil Procedure promulgated by the Suprenie Court of the United States! One hopes that higher courts will in tune suppress this disunionist uprising and cause Eastern Texas to

† Chadwick Professor of Law, Duke University; Reporter, Civil Rules Advisory Committee, Judicial Conference of the United States, 1985-92. Edward Cooper and Charles Alan Wright, as they have so often done, saved me from several errors, but are surely not responsible for any that remain. Wayne Brazil, Dan Coquillette, Tom Metzloff and Preble Stolz made useful suggestions. Of course, none of these persons are responsible for my heresies. Jeff Prescott and Erik Beleuky helped with the documentation. Erika King made many useful editorial suggestions. I also salute the memory of Maurice Rosenberg, with whom I discussed these issues over three decades of joyful comradeship.

1. Culberson was born in $\mathbf{1 8 3 0}$ in Troup County, Georgia. He was admitted to the Texas bar in 1851 and practiced first in Gilmer, then in Dallas. He was elected to Congress in 1874 from a largely rural district that included much of Eastern Texas. He served twelve terms in the House of Representatives. CHARLES LANMAN, BIOGRAPHICAL ANNALS OF THE Civil Government of THE UNITEd States, DURING ITS FIRST CENTURY (James Anglim 1876). Culberson was a sponsor of the Evarts Act of 1891, a measure intended to diminish the discretion of individual federal judges. See infra, at notes 30-37.

2. 28 U.S.C. $\S \S 472-473$ (1994).

3. Act of June 19, 1934, ch. 651, 48 Stat. 1064.

4. Act of Nov. 19, 1988, Pub. L. No. 100-702, § 401(a), 102 Stat. 4648, 4648-50 (codified as aunended at 28 U.S.C. $\$ \$ 2072-2074$ (1988)).

5. 28 U.S.C. $\S 1920$ (1988).

6. 28 U.S.C. $\S 1652$ (1988). 
rejoin the union of the federal judiciary, but meanwhile that court has provided us with an unusual example of judicial mischief, and with cause to wonder if the services of Grant or Culberson might be needed.

At the moment, the mischief in Eastern Texas is still good fun; few, if any, appear to have been seriously hurt. The mischief began with a simple declaration in the court's Cost and Delay Reduction Plan promulgated in response to the CJRA that its Plan would take precedence over the Federal Rules of Civil Procedure promulgated by the Supreme Court pursuant to the Rules Enabling Act. National rules would apply only when the local rules did not. ${ }^{7}$ It then included in its Plan a fee-shiftmg offer-ofsettlement rule $^{8}$ that was substantially more coercive than Rule 68 of the Federal Rules, ${ }^{9}$ and also undertook in its Plan to regulate

7. "To the extent that the Federal Rules of Civil Procedure are inconsistent with this Plan, this Plan has precedence and is controlling." United States District Court for the Eastern District of Texas, Civil Justice Cost and Delay Reduction Plan 9 (Dec. 20, 1991) (on file with author).

8. Art. $6, \S 9$ provides:

At the Management Conference or anytime thereafter, a party may make a written offer of judgment. If the offer of judgment is not accepted and the final judgment in the case is of more benefit to the party who made the offer by $10 \%$, then the party who rejected the offer must pay the litigation costs incurred after the offer was rejected. In personal injury and civil rights cases involving contingent attorneys' fees, the award of hitigation costs slall not exceed the amount of the final judgment. The court may, in its discretion, reduce the award of hitigation costs in order to prevent undue hardship to a party. "Litigation costs" neaus those costs which are directly related to preparing the case for trial and actual trial expenses, imcluding but not limited to reasonable attorneys' fees, deposition costs and fees for expert witnesses.

9. Rule 68 provides for offers of judgment, i.e. offers of settlement to be embodied in a court order. Its text reads:

At any time more than 10 days before the trial begins, a party defending against a claim may serve upon the adverse party an offer to allow judgment to be taken against the defending party for the money or property or to the effect specified in the offer, with costs then accrued. If within 10 days after the service of the offer the adverse party serves written notice that the offer is accepted, either party may then file the offer and notice of acceptance together with proof of service thereof and thereupon the clerk shall enter judgment. An offer uot accepted shall be deemed withdrawn and evidence thereof is not admissible except in a proceeding to determine costs. If the judgment fmally obtained by the offeree is not more favorable than the offer, the offeree must pay the costs mcurred after the making of the offer. The fact that an offer is made but not accepted does not preclude a subsequent offer. When the liability of one party to another has been determined by verdict or order of judgment, but the amount or extent of the liability remains to be determined by further proceedings, the party adjudged hable may make an offer of judgment, which shall have the same effect as an offer made before trial if it is served within a reasonable time not less than 10 days prior to the commencement of hearings to determine the amount or extent of liability.

FED. R. CIV. P. 68. 
the fees paid by plaintiffs to their attorneys. On their face, these rules seem apphicable to all parties litigating in that court, whether the claims or defenses they assert arise under federal or state law, and whether the actions to which they are parties were coinmenced in federal court or removed there by the defendants. In a recent decision, Friends of the Earth v. Chevron Chemical Co., ${ }^{10}$ the court rejected a cliallenge to its coercive offer-of-settlement rule, but held it inapplicable to plaintiffs suing to enforce the federal Clean Water Act, ${ }^{11}$ lest its Plan deter a class of plaintiffs whoin Congress by that legislation wanted to encourage. It defended its Plan as one authorized by the 1990 Act despite its conflict witl recently enacted and unrepealed sections of the Judicial Code of the United States forbidding district courts to make rules inconsistent with the national law. The court took no notice of the ancient Rules of Decision Act forbidding the displacement of substautive state law, or of the ancient legislation limiting taxable costs. And it gave only glancing attention to the Constitution of the United States which, at least arguably, it violated three times im a single breatl. It concluded that it was enipowered to make any rule that might reduce cost or delay, however those phenomena miglit be defined.

Given the hubris expressed in the court's Plan, the decision was not surprising. The case is significant because it dramatically marks a widely observed trend $d^{12} \mathrm{~m}$ the evolution, or devolution, of the professionalism of the federal judiciary, a professionalisin im which the endangered Federal Rules of Civil Procedure have played a significant part. Unfortunately, Friends of the Earth will uot be reviewed by a higher court. So the local plan awaits future application, nost likely to hitigants in diversity cases who invoke

10. 885 F. Supp. 934 (E.D. Tex. 1995).

11. Federal Water Pollution Control Act, Pub. L. No. 92-500, 86 Stat. 816 (1972) (codified as amended at 33 U.S.C. $\$ 1344$ et seq.).

12. See, e.g., Linda S. Mullenix, The Counter-Reformation in Procedural Justice, 77 MinN. L. REv. 375 (1992) [hereinafter Counter-Reformation]; Judith Resnik, Failing Faith: Adjudicatory Procedure in Decline, 53 U. CHI. L. REV. 494 (1986) (chronicling 50 years of commentary on the Federal Rules of Civil Procedure); Jeffrey W. Stempel, Halting Devolution or Bleak to The Future: Subrin's New-Old Procedure as a Possible Antidote to Dreyfuss's "Tolstoy Problem," 46 FLA. L. REV. 57 (1994) (detailing the "case management" procedural philosophy of the judiciary and some reformers as flawed); Stephen N. Subrin, Teaching Civil Procedure While You Watch It Disintegrate, 59 BRoOK. L. REV. $1155,1155-72$ (1993) (describing the "sea change" in philosophy behind procedural rules beginning in the 1870s). 
mere state-created rights and who are hence not exempt from the coercive local plan.

\section{The Advent and Decline of Private ENFORCEMENT OF THE NATIONAL LAW}

To put Friends of the Earth in perspective, a brief review of the historical role of the U.S. District Courts is useful. It may be recalled that until 1875 , the federal trial courts were exercising httle responsibility for the enforcement of national law, in part because there was little national law to enforce. The diversity and admiralty jurisdictions formed the core of their business. ${ }^{13}$ Their procedure was fashioned locally to resemble practice in neighboring state courts, with the blessing of Congress expressed in the Conformity Act $^{14}$ and its antecedents. ${ }^{15}$ Despite the reforms of state practice that commenced in New York in $1848,{ }^{16}$ nineteenth century civil procedure was a sport of chance in which the substantive inerits of claims and defenses played a minor role. ${ }^{17}$ Moreover, review by the Supreme Court of the United States ${ }^{18}$ was remote, and not only in distance, for the Court was not likely to entertain an appeal for as many as three years or more ${ }^{19}$ and would entertain only a narrow range of assignments of error ${ }^{20}$

13. Felix Frankfurter \& JAMEs M. LANDis, The Business of the Supreme COURT 12 (1928).

14. Act of June 1, 1872, ch. 255, 17 Stat. 196.

15. A similar provision was first enacted in the Act of Sept. 29,1789 , ch. $21, \S 2,1$ Stat. 93-94.

16. See Robert W. Millar, Civil Procedure of the Trial Court in HistoriCAL PERSPECTIVE 52-64 (1952); Steven N. Subrin, David Dudley Field and the Field Code: A Historical Analysis of an Earlier Procedural Vision, 6 LAw \& HIST. REV. 311 (1988) (describing the history of the Field Code and its progenitor).

17. Roscoe Pound, The Causes for Popular Dissatisfaction with the Administration of Justice, 40 AM. L. REV. 729, 738-40 (1906).

18. A limited appellate jurisdiction was conferred on the circuit courts by the 1789 Act. See Act of Sept. 24, 1789, ch. 20, $\S 21,22,1$ Stat. 73, 83-85. The circuit courts were abolished by the Act of Mar. 3, 1911, ch. 231, $\S 289,36$ Stat. 1087, 1167.

19. The availability of the Court is described in FRANKFURTER \& LANDIS, supra note 13 , at $60-70$.

20. See generally Roscoe Pound, APPEllate Procedure IN Civil Cases 106-321 (1941); Edson R. Sunderland, The Problem of Appellate Review, 5 TEX. L. REV. 126, $139-46$ (1927). For adverse comments on this evolution, see LEON GREEN, JUDGE AND JURY 380 (1930) ("Froin the moment that the appellate courts became a separate organization froin the trial courts, a silent and probably unconscious struggle for supremacy began, which has resulted not ouly in complete subordination of trial judges but also of juries."); Carleton M. Crick, The Final Judgment as a Basis for Appeal, 41 YALE L.J. 
Therefore, a decision by a single judge was the terminal point for most hitigants im federal courts. Federal trial courts bore an uncomfortable resemblance to the eighteenth century Enghish Court of Chancery, in which the king's Chancellor wielded unreviewed discretionary power over the lives and properties of higants coming before him. ${ }^{21}$ Chancery cases, we recall hearing, were decided according to the length of the Chancellor's foot. ${ }^{22}$ In fact, at least with respect to the expansive application of the contempt power, the courts of the United States exercised even greater power than the ancient chancellors. ${ }^{23}$

Sonietimes the discretionary power of the federal trial judge was used wisely, but it was deeply resented by many. Federal judges in the nineteenth century, like lords of the manor, were niore feared than honored. The Judiciary Act of $1875^{24}$ enlarged their power by establishing federal question jurisdiction, so that claims arising under the growing body of federal legislation could be brought before a federal judge. This enactnient, and the constitutional provision on which it rests, reflected a presumption that federal judges have a stronger professional commitment to the enforcement of the national law than locally elected state judges. The Civil Rights Acts of $1866,{ }^{25} 1871,{ }^{26}$ and $1875^{27}$ were among the first laws enacted by Congress with a view to private enforce-

539, 548-65 (1932) (arguing against the use of mandamus proceeding to expand the scope of review); Charles A. Wright, The Doubtful Omniscience of Appellate Courts, 41 MINN. L. REV. 751, 778-82 (1957) (arguing that the range of errors reviewable by appellate courts was increasing rapidly); Charles A. Wright, The Federal Courts-A Century After Appomattox, 52 A.B.A. J. 742, 748 (1966) (arguing that the scope of appellate review should be restricted).

21. See Stephen N. Subrin, How Equity Conquered Common Law: The Federal Rules of Civil Procedure in Historical Perspective, 135 U. PA. L. REV. 909, 918-21 (1987).

22. See Table Talk of John Selden 43 (Frederick Pollock ed., 1927). Cf. Stephen B. Burbank, The Chancellor's Boot, 54 BROOK. L. REv. 31 (1988) (commenting on a federal judge who manages his court irrespective of the Rules).

23. RONALd L. Goldfarb, THE CONTEMPT POWER 45 (1964); see also Walter Nelles, The Summary Power to Punish for Contempt, 31 COL. L. REV. 956 (1931) (discussing origins and applications of contempt power).

24. Act of Mar. 3, 1875, ch. 137, 18 Stat. 470. The immediate impetus for this legislation was The Case of the Sewing Machine Companies, 85 U.S. (18 Wall.) 553 (1873). See FRANKFURTER \& LANDIS, supra note 13, at 66-68.

25. Act of Apr. 9, 1866, ch. 31, 14 Stat. 27 (1866) (codified as amended at 42 U.S.C. $\S 1981$ (1988)).

26. Act of Apr. 20,1871 , ch. $22, \S 1,17$ Stat. 13 (1871) (codified as amended at 42 U.S.C. $\S 1981$ (1988)).

27. Act of Mar. 1, 1875, ch. 114, 18 Stat. 335. 
ment in the federal courts. But for the reasons noted, the federal courts then existing were not well suited to such tasks; the 1875 Judiciary Act intensified the widely shared mistrust of the federal judiciary as being arrogant and unfeeling autocrats. In those days, removal jurisdiction was a field on which inany battles were vigorously fought, ${ }^{28}$ lawyers for injured workmen, for example, struggled desperately to keep their cases out of federal court. ${ }^{29}$

A response to this situation was the Evarts Act of $1891,{ }^{30}$ which created the U.S. Courts of Appeals. The Act was intended to subordinate the local potentates sitting on the benches of U.S. trial courts. They were made a functioning part of a unified judicial systein designed to enforce national law evenhandedly across the continent. The draftsman and proponent of that legislation in the Senate was Williain Maxwell Evarts of New York, perhaps in his time the most respected practicing lawyer in America. ${ }^{31}$ His principal ally in the House of Representatives was David Culberson, the agrarian lawyer from Texas. Some may still feel Culberson's passion when he told his fellow Congressmen that he had "a supreme desire to witness during ... [his] time in Congress the overthrow and destruction of the kingly power" of the federal judges. ${ }^{32}$

The legislation of 1891 had that desired effect. In achieving the "overthrow of kingly power," it followed an estabhished pattern of American pohitics. The overbearing and inadequately controlled conduct of the royal judges had been a grievance agamst the British crown corrected by force of arms. ${ }^{33}$ Fear of unre-

28. EDWARD A. PURCELl, JR., LITIGATION AND INEQUALITY: FEDERAL Diversity JURISDICTION IN INDUSTRIAL AMERICA, 1870-1958, at 104-47 (1992). One of the most widely used law books in the nineteenth century was JOHN F. DILLON, REMOVAL OF CAUSES FROM STATE COURTS TO FEDERAL COURTS WITH ForMS ADAPTED TO THE SEVERAL ACTS OF CONGRESS ON THE SubJECT (1877). It went through numerous editions.

29. PURCELL, supra note 28, at 104-26.

30. Act of Mar. 3, 1891, ch. 517, 26 Stat. 826.

31. Evarts was known for his successful defense of President Johnson in the impeachment proceeding, as an officer in the cabinets of Presidents Grant and Hayes, and as the founding spirit of the Association of the Bar of the City of New York. See CHEster L. Barrows, WM. M. EVARTS: LAwYER, Diplomat, Statesman 138-79, 182-84, 311-32 (1941).

32. 21 CONG. REC. 3403,3404 (1890).

33. E.g., THE DECLARATION OF INDEPENDENCE para. 11 (U.S. 1776) ("[George III] has made Judges dependent on his Will alone, for the tenure of their offices, and the amount and payment of their salaries."). Among the first decisions of several state consti- 
strained federal judicial power had animated the anti-federalists to demand and receive ratification of the Seventh Amendment guaranteeing the right to jury trial in civil cases. ${ }^{34}$ In his first presidential message, President Jefferson expressed his mistrust of judicial power, urging that the right to jury trial be extended to suits in equity. ${ }^{35}$ And it was hostility to judicial hubris that energized the Jacksonian movement in the mid-nineteenth century to establish popular election of judges in most states. ${ }^{36}$ Indeed, nowhere was the resistance to judicial authority greater than in nineteenth century Texas. Its constitution, drafted by agrarians and fugitive debtors, provided for the election of judges to short terms; its judges dared not wear robes or comment to the jury on the evidence. ${ }^{37}$ Congressman Culberson was thus not the first Texan, nor the last, to stand in opposition to "kingly power" in the judiciary.

The 1934 Rules Enabling $\mathrm{Act}^{38}$ was a political triumph of the American Bar Association, ${ }^{39}$ not an agrarian reform; but it too had as one goal the unification of the federal judiciary to serve the common purpose of enforcing rights created by national law. On that account, it enjoyed the support, indeed the zealous advocacy, of nationalists as diverse in their politics as Williain Howard Taft and Charles Edward Clark, a committed New Dealer. The decision of the Supreme Court in 1938 in Erie R.R. v.

tutional conventions was the abolition of chancery. E.g., J. PAUL SELSAM, THE PENNSYLVANIA CONSTITUTION OF 1776, at 196-99 (1936).

34. See generally Charles W. Wolfram, The Constitutional History of the Seventh Amendment, 57 MINN. L. REV. 639 (1973). The Pennsylvania anti-federalists, for example, prepared the most coherent statement of the reasons for opposing ratification. They gave a prominent, if not primary, place to the threatening character of the federal judiciary resulting from the failure of the Constitution to guarantee the right to jury trial im civil cases. THE ANTIFEDERALISTS 49-51 (Cecilia Kenyon ed., 1966).

35. 2 WRITINGS of Thomas JeFFERSON 177 (P. Ford ed., 1985). For earher expressions of this idea by Jefferson, see 9 id. at 340; see also 5 id. at 224.

36. See Daun van Ee, David Dudley Field and the Reconstruction of AMERICAN LAW 113-161 (1986). See generally MARVIN MEYERS, THE JACKSONIAN PERSUASION (1957).

37. See Daffan Gilmer, Early Courts and Lawyers of Texas, 12 TEx. L. REv. 435 (1934); Clarence Wharton, Early Judicial History of Texas, 12 TEX. L. REV. 311 (1934). For a discussion of populism in Texas, see generally LAWRENCE GOODWYN, DEMOCRATIC PROMISE (1976).

38. Pub. L. No. 73-415, 48 Stat. 1064 (1934).

39. Stephen B. Burbank, The Rules Enabling Act of 1934, 130 U. PA. L. REV. 1015, 1043-98 (1982). 
Tompkins ${ }^{40}$ pursued the closely related purpose of reinforcing the integrity of state law ${ }^{41}$ by making federal courts accountable for their fidehity to state law when it appropriately controls, as in diversity litigation. ${ }^{42}$

The discovery rules ${ }^{43}$ promulgated that same year further elevated the law-enforcing role of the federal courts. ${ }^{44}$ Not only were federal courts committed to enforcing law in civil cases, but they were assured of being more able to investigate and discern facts in dispute than any courts had ever been. The private bar serving as officers of the courts were commissioned to use the courts' subpoena power to investigate a wide range of possibly unlawful conduct. ${ }^{45}$

Critics doubted that the imcreased accuracy in the application of the law was worth the cost to the litigants of the new methods of investigation. ${ }^{46}$ But by the mid-1960s, the federal courts had replaced admimistrative agencies as the preferred means of enforcmg much of our national law. Unlike administrative agencies and other political bodies in any government anywhere, the federal courts, their juries, and the private bar serving them were alınost invulnerable to political manipulation, intimidation, or bribery in any of their nuany forms. ${ }^{47}$ The federal district court was therefore as close to a level playing field as any public forum had ever

40. 304 U.S. 64 (1938).

41. For a contrasting explanation of the link, see Jack B. Weinstein, The Ghosts of Process Past: The Fiftieth Anniversary of the Federal Rules of Civil Procedure and Erie, 54 BROOK. L. REV. 1, 19-21 (1988).

42. This responsibility was reconfirmed in Salve Regina College v. Russell, 499 U.S. 225, 227 (1991).

43. FED. R. CIV. P. 26-37.

44. Edson R. Sunderland, Discovery Before Trial Under the New Federal Rules, 15 TENN. L. Rev. 737, 738-39 (1939); cf. Edson R. Sunderland, Scope and Method of Discovery Before Trial, 42 YALE L.J. 863 (1934); Edson R. Sunderland, Improving the Administration of Civil Justice, 167 ANNALS AM. ACAD. POL. \& SOC. SCI. 60 (1933).

45. See generally William A. Glaser, PRETRIAL DisCOVERY AND THE AdVERSARY SYSTEM (1968) (presenting results of extensive survey on modern discovery rules and the effect they have had on the administration of American justice).

46. Willian H. Speck, The Use of Discovery in the United States District Courts, 60 YALE L.J. 1132, 1132-33 (1951).

47. But compare John H. Langbein, The German Advantage in Civil Procedure, 52 U. CHI. L. REv. 823, 853-55 (1985) (contrasting the influence of politics in the selection of American judges with the more bureaucratic German approach) with Samuel R. Gross, The American Advantage: The Value of Inefficient Litigation, 85 MICH. L. REV. 734, $742-44$ (1987) (arguing that adversarial discovery, while more inefficient, is nonetheless more accurate than a nonadversarial system). 
been. ${ }^{48}$ Armed with the contempt power, ${ }^{49}$ the federal courts were indeed a daunting threat to anyone considering a possible violation of the national law potentially injurious to the rights of others. ${ }^{50}$ Law enforcement in civil cases, not mere dispute resolution, became the primary business of the federal courts. ${ }^{51}$ Primarily enforced through civil hitigation were laws deterring trade practices injurious to inarkets in goods and fraud imjurious to investment markets, laws protecting civil rights and civil liberties, and laws protecting the environment. Whereas other countries rehed upon administrative bureaucracies to protect the public interest in these large and important areas, America rehed primarily upon its courts because they proved to be more effective.

State courts and legislatures in most states soon perceived this effect and replicated the federal practice in their state courts. ${ }^{52}$ More frequently than ever before, American lawyers were giving their chents the unwelcome advice that unlawful conduct harmful to others would likely be detected and the law enforced. In short, American law became surprisingly effective. This development coincided with the steady rise in the rights-consciousness of the American people. It also coincided with a modest expansion of the appellate jurisdiction of the U.S. Courts of Appeals. While district courts were given inore discretion to administer pretrial practice, ${ }^{53}$ there was an erosion of the final decision requirement that

48. See Weinstein, supra note 41, at 25 (arguing that the Federal Rules spurred "an enormous effort, almost a quantum jump, toward equality in fact").

49. The contempt power to enforce injunctions is not available elsewhere and is generally regarded as "a legal technique which is not only unnecessary to a working legal system, but also violative of basic philosophical approaches to the relations between government bodies and people." GoldFARB, supra note 23, at 2 (footnote omitted).

50. Cf. Abrain Chayes, The Role of the Judge in Public Law Litigation, 89 HARv. L. REV. 1281, 1292-96, 1298-1302 (1976) (surveying the changing paradigm of federal litigation, including greater use of equitable rehef, prospective decrees, and contempt power).

51. See Kenneth E. Scott, Two Models of the Civil Process, 27 STAN. L. REV. 937, 938-40 (1975); John C. Coffee, Jr., Understanding the Plaintiff's Attorney: The Implications of Economic Theory for Private Enforcement of Law Through Class and Derivative Actions, 86 COLUM. L. REV. 669, 669 \& n.1 (1986).

52. "The [Federal] Rules may be Bleak House, but everyone seems to want to live there." Geoffrey C. Hazard, Jr., Undemocratic Legislation, 87 YALE L.J. 1284, 1287 (1978) (book review) (footnote omitted).

53. Stephen C. Yeazell, The Misunderstood Consequences of Modern Civil Process, 1994 WIS. L. REV. 631, 640-66. Yeazell observes that the increased emphasis on pretrial practice enlarged the power of the district courts vis-à-vis the courts of appeals. That is doubtless true, but there was in the early decades of the 1938 rules a compensatory adjustment in the compass of appellate jurisdiction. See also Judith Resnik, From "Cases" 
enabled courts of appeals to cabin that discretion, so to ensure that federal judgments conform to the controlling law. ${ }^{54}$ The U.S. District Judge, although powerful, was now accountable to a degree that no chancellor sitting in the high court of Chancery ever was.

Over the last three decades, there has been a degeneration of federal civil practice. Friends of the Earth manifests that degeneration and is therefore a matter for national interest and concern. What has degenerated is not the professionahsm of individual members of the federal judiciary, for their standards are generally high, perhaps as high as they have ever been, but diminishing is their collective sense that the enforcement of legal rights and duties is their primary business. I have been among those calling attention to various aspects of this phenomenon with the frequency of a broken record; 5 but there was nothing in my reportage

to "Litigation," LAw \& CONTEMP. PROBS., Summer 1991, at 5, 57-60 (describing this adjustment in the context of coinplex tort cases); Arthur R. Miller, The Adversary System: Dinosaur or Phoenix, 69 MINN. L. REv. 1, 19-22 (1984) (advocating increased judicial inanagement).

54. E.g., Carson v. American Brands, Inc., 450 U.S. 79, 83-86 (1981); Thermtron Products, Inc. v. Hermansdorfer, 423 U.S. 336, 342-56 (1976); Gillespie v. Umited States Steel Corp., 379 U.S. 148, 152-54 (1964); Schlagenhauf v. Holder, 379 U.S. 104, 109-12 (1964); Beacon Theatres, Inc. v. Westover, 359 U.S. 500, 501-11 (1959); La Buy v. Howes Leather Co., 352 U.S. 249, $254-55$ (1957); Cohen v. Beneficial Indus. Loan Corp., 337 U.S. 541, 545-47 (1949); Thiel v. Southern Pac. Co., 328 U.S. 217, 220-25 (1946); Galloway v. United States, 319 U.S. 372, 388-96 (1943). See generally Martin H. Redish, The Pragmatic Approach to Appealability in the Federal Courts, 75 Colum. L. REV. 89 (1975) (discussing the final judgment rule). At one time, it was possible to say plausibly that "an order, otherwise nonappealable, determining substantial rights of the parties which will be irreparably lost if review is delayed until final judgment may be appealed immediately under Section 1291." United States v. Wood, 295 F.2d 772, 778 (5th Cir. 1961), cert. denied, 369 U.S. 850 (1962). Current standards of appealability are somewhat more restrained. See generally MichaEL E. TIGAR, FEDERAL APPEALS JuRISDiCtION AND PRACTICE 76-81 (2d ed. 1993).

55. See Paul D. CARRINGton et AL., Justice on APPEAL (1976) [hereinafter JusTICE ON APPEAL]; Paul D. Carrington, U.S. Courts of Appeals and U.S. District Courts: Relationships in the Future, in THE FEDERAL APPELLATE JUDICIARY IN THE 21ST CENTURY 69 (Cynthia Harrison \& Russell R. Wheeler, eds., 1989) [hereinafter Relationships in the Future]; Paul D. Carrington, An Unknown Court: Appellate Caseload and the "Reckonability" of the Law of the Circuit, in RESTRUCTURING JUSTICE: THE INNOVATIONS OF THE NINTH CIRCUIT AND THE FUTURE OF THE FEDERAL COURTS 206 (Arthur D. Hellman, ed., 1990) [hereinafter An Unknown Court]; Paul D. Carrington, Crowded Dockets and the Courts of Appeals: The Threat to the Function of Review and the National Law, 82 HARV. L. REV. 542 (1969); Paul D. Carrington, The Power of District Judges and the Responsibility of Courts of Appeals, 3 GA. L. REV. 507 (1969); Paul D. Carrington, United States Appeals in Civil Cases: A Field and Statistical Study, 11 Hous. L. REv. 1101 (1974); Paul D. Carrington, Current Developinents in Judicial Administra- 
that was not also being observed by many others. ${ }^{56}$ Many of the anxieties expressed over that time are captured in the recent report of the Long Range Planning Committee of the Judicial Conference of the United States. ${ }^{57}$ That Report sounds an urgent note, foretelling an unnamed dooin if something is not done.

But the sky is not falling. The federal judiciary will not collapse so long as the republic stands. What is being lost is an ephemeral quality of our national life, so ephenieral that it is easy for those immediately engaged in professional work to overlook the loss. The decline is directly fatal to no particular interest, but is not without value to the public. As the courts' collective, institutional professional commitment to decide civil cases by applying law to facts dimimishes, the worth of all rights, claims, and defenses enforceable in those courts diminish as well. Government is accordingly less effective and has a smaller entitlenent to the respect and loyalty of its citizens. Such ineffable losses are not the sort to show up on a balance sheet ${ }^{58}$ or a score card or an opinion poll, but they are not less costly on that account, especially in

tion, Address Before the Plenary Session of the American Association of Law Schools (Dec. 28, 1977), in 80 F.R.D. 147, 180 (1979); Paul D. Carrington, Ceremony and Realism: Demise of Appellate Procedure, 66 A.B.A. J. 860 (1980) [hereinafter Ceremony and Realism]; Paul D. Carrington, Perspectives on Improving the Work of Our Courts, Address Before the Second Judicial Circuit Judicial Conference (May 9, 1981), in 93 F.R.D. 673, 735 (1982); Paul D. Carrington, Civil Procedure and Alternative Dispute Resolution, 34 J. Legal Educ. 298 (1984); Paul D. Carrington, The Function of the Civil Appeal: A Late Century View, 38 S.C. L. REv. 411 (1987); Paul D. Carrington, Making Rules to Dispose of Manifestly Unfounded Assertions: An Exorcism of the Bogy of Non-Trans-Substantive Rules of Civil Procedure, 137 U. PA. L. REV 2067 (1989) [hereinafter Making Rules]; Paul D. Carrington, The New Order in Judicial Rulemaking, 75 JUdICATURE 161 (1991); Paul D. Carrington, Meaning and Professionalism in American Law, 10 CoNST. COMMENTARY 297 (1993); Paul D. Carrington, William Gardiner Hammond and the Lieber Revival, 16 CARDOZO L. REV. 2135 (1995).

56. See, e.g., Oweu M. Fiss, Out of Eden, 94 YALE L.J. 1669 (1985); Owen M. Fiss, Against Settlement, 93 YALE L.J. 1073 (1984); Richard L. Marcus, Of Babies and Bathwater: The Prospects for Procedural Progress, 59 BROOK. L. REV. 761, 762-80 (1993); Resnik, supra note 12.

57. See Committee on long Range Planning, judiclal Conference of the UNITED STATES, LONG RANGE PLAN FOR THE FEDERAL COURTS (1995).

58. For efforts at economic analysis, see Edward H. Cooper, Discovery Cost Allocation: Comment on Cooter \& Rubinfeld, 23 J. LEGAL STUD. 465 (1994); Robert D. Cooter \& Daniel L. Rubinfeld, An Economic Model of Legal Discovery, 23 J. LEGAL STUD. 435 (1994); Bruce L. Hay, Civil Discovery: Its Effects and Optimal Scope, 23 J. LEGAL STUD. 481 (1994); Louis Kaplow, The Value of Accuracy in Adjudication: An Economic Analysis, 23 J. LEGAL STUD. 307 (1994). 
a culture relying as ours does on law as the adhesive force binding a diverse population together.

The decline in the judicial professionahisin of the federal courts is inanifested in the following ways, perhaps among others:

(1) the gradual diversion of the energies of circuit judges away from the humdrum task of listening to arguments based on the minutiae of appellate records for the purpose of assuring fidelity to law, in favor of the seemingly more uplifting work of proclaiming new law in opinions of the court; ${ }^{59}$

(2) the declining predictability of appellate decisions inaking lawyers and trial judges less reliant on the utterances of U.S. Circuit Judges-a decline caused by steady enlargenent of the courts of appeals without structural modification to assure colierence; ${ }^{.00}$

(3) the growing preoccupation of district judges with adıninistration, as distinct from enforcement, or, in other words, with moving cases rather than deciding them; ${ }^{61}$

(4) the growing involvement of district judges and magistrate judges in "managing" pretrial hitigation in cases that will never be decided on their merits, ${ }^{62}$ often to control "discovery abuse" by counsel, ${ }^{63}$

(5) the increasing pressure placed by district courts on the parties to civil disputes to settle their differences, ${ }^{64}$ a practice until re-

59. JUSTICE ON APPEAL, supra note 55.

60. Relationships in the Future, supra note 55, at 71 ; Ceremony and Realism, supra note 55 , at 863 .

61. Lauren K. Robel, Caseload and Judging: Judicial Adaptations to Caseload, 1990 B.Y.U. L. REv. 3. See also Marc Galanter, The Emergence of the Judge as a Mediator in Civil Cases, 69 Judicature 256 (1986).

62. See also Steven Flanders, Federal Judicial Center, Case Management AND COURT MANAGEMENT IN UNITEd STATES DisTRICT CouRTS 37-38 (1977); E. Donald Elliott, Managerial Judging and the Evolution of Procedure, 53 U. CHI. L. REv. 306 (1986); Richard L. Marcus, Public Law Litigation and Legal Scholarship, 21 U. Mich. J.L. REF. 647, 660-82 (1988); Richard L. Marcus, Completing Equity's Conquest? Reflections on the Future of Trial Under the Federal Rules of Civil Procedure, 50 U. PITT. L. REV. 725, 743-45 (1989); Robert F. Peckham, The Federal Judge as a Case Manager: The New Role in Guiding a Case from Filing to Disposition, 69 CAL. L. REv. 770 (1981); Judith Resnik, Managerial Judges, 96 HARV. L. REv. 374 (1982).

63. For a brief account of discovery abuse, see Geoffrey C. Hazard, Jr., Discovery Vices and Trans-Substantive Virtues in the Federal Rules of Civil Procedure, 137 U. PA. L. REV. 2237, 2237-44 (1989) [hereinafter Vices].

64. The use of alternative dispute resolution devices such as nonbinding arbitration is the preferred method. The most recent federal legislation promoting that technique is Act of Dec. 14, 1993, Pub. L. No. 103-92, 107 Stat. 2292 (codified at 28 U.S.C. $\$ \S 651-58$ (1988)). Whether courts are justified in requiring resort to such devices is subject to doubt and nuch criticism. For powerful critiques, see Edward Brunet, Questioning the 
cent times regarded as unethical; ${ }^{65}$

(6) the growing practice of compelling reluctant parties, in coinphance with contracts of adhesion, to engage in binding arbitration of claims brought to enforce regulatory laws of the Umited States and of the states;

(7) the increasing use of joimder devices and enlarged principles of res judicata to preclude the assertions of claims and defenses without a full hearing on the merits; ${ }^{67}$

Quality of Alternate Dispute Resolution, 62 TUL. L. REV. 1 (1987); Kim Dayton, The Myth of Alternative Dispute Resolution in the Federal Courts, 76 IowA L. REV. 889 (1991); Harry T. Edwards, Alternative Dispute Resolution: Panacea or Anathema?, 99 HARV. L. REV. 668 (1986); see also Robert A. Baruch Bush, Dispute Resolution Alternatives and the Goals of Civil Justice: Jurisdictional Principles for Process Choice, 1984 WIS. L. REV. 893; Richard Delgado et al., Fairness and Formality: Minimizing the Risk of Prejudice in Alternative Dispute Resolution, 1985 WIS. L. REv. 1359; Carrie Menkel-Meadow, Pursuing Settlement in an Adversary Culture: $A$ Tale of Innovation Co-Opted or "The Law of $A D R$," 19 FLA. ST. U. L. REV. 1 (1991); Leonard L. Riskin, The Represented Client in a Settlement Conference: The Lessons of G. Heileman Brewing Co. v. Joseph Oat Corp., 69 WASH. U. L.Q. 1059 (1991). For empirical accounts, see FREDERICK B.

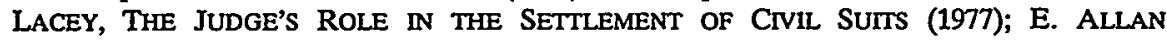
LIND \& JOHN E. SHEPARD, FEDERAL JudiCIAL CTR., EVALUATION OF COURT-ANNEXEd ARBITRATION IN THREE FEDERAL DISTRICT COURTS (rev. ed. 1983); Barbara S. MEIERHOEFER, COURT-ANNEXEd ARBITRATION IN TEN DisTrictS (1990); D. MARIE Provine, SeTtlement Strategies For Federal District Courts (1986); Marc Galanter \& Mia Cahill, "Most Cases Settle": Judicial Promotion and Regulation of Settlements, 46 STAN. L. REV. 1339 (1994); Richard Posner, The Summary Jury Trial and Other Methods of Alternative Dispute Resolution: Some Cautionary Observations, $53 \mathrm{U}$. CHI. L. REv. 366 (1986); Joshua D. Rosenberg \& H. Jay Folberg, Alternative Dispute Resolution: An Empirical Analysis, 46 STAN. L. REV. 1487 (1994); Hubert L. Will, et. al., The Role of the Judge in the Settlement Process, 75 F.R.D. 203 (1977).

65. George Whartou Pepper, a distinguished member of the Philadelphia bar and a member of the original Rules Advisory Committee, hoped to write a rule that would make the practice an impeachable offense. David L. Shapiro, Federal Rule I6: A Look at the Theory and Practice of Rulemaking, 137 U. PA. L. REV. 1969, 1980 n.38 (1989).

66. This has resulted from a transformation of the Federal Arbitration Act of 1925, 9 U.S.C. $\$ \S 1-15$ (1988) stemming from a reinterpretation of the Act by the Supreme Court in opimions written since 1967. See generally IAN R. MACNEIL, AMERICAN ARBITRATION LAW 134-47 (1992).

67. Robert G. Bone, Mapping the Boundaries of a Dispute: Conceptions of Ideal Lawsuit Structure from the Field Code to the Federal Rules, 89 Colum. L. REV. 1, 104-118 (1989); Linda S. Mullenix, Class Actions, Personal Jurisdiction, and Plaintiffs' Due Process: Implications for Mass Tort Litigation, 28 U.C. DAVIS L. REV. 871, 887-908 (1995); Mark A. Peterson \& Molly Selvin, Mass Justice: The Limited and Unlimited Power of Courts, LAW \& CONTEMP. FROBS., Summer 1991, at 227; Resnik, supra note 53, at 5; Peter Schuck, The Role of Judges in Settling Complex Cases: The Agent Orange Example, 53 U. CHI. L . REV. 337, 341-48, 362-65 (1986); Jay Tidmarsh, Unattainable Justice: The Form of Complex Litigation and the Limits of Judicial Power, 60 GEO. WASH. L. REV. 1683, 1783-89 (1992). 
(8) the halving of juries in most districts, making juries more prone to render idiosyncratic verdicts; ${ }^{68}$

(9) the proliferation of delegates performing judicial work in all federal judicial chanbers to include magistrate judges, bankruptcy judges, special masters, court-annexed-arbitrators, mediators, neutral evaluators, law clerks, interus, exterus, and other go-fers, with the result that judges at all levels are in danger of becoining mere trademarks for the professional work of others, ${ }^{69}$ and (10) the proliferation of local rules, standing orders, plans and other like instruments reflecting claims to local autonomy. ${ }^{70}$

I do not here contend that any one of these trends standing alone ought be viewed as a serious threat to due process of law. For example, court-annexed mediation can, if so used, facilitate definition of the issues to be hitigated, and so reduce the need for discovery and inprove the quality of trials. But as generally observed in practice, all of these developments manifest a ineasure of disregard for accuracy in applying law to facts in the resolution of civil disputes, or, as Judith Resnik has put it, a "failing faith."71 A lost horizon in this grasp for readier resolutions of disputes is that for most disputes the best means available to induce economy and peaceful resolution is to assure prompt and accurate apphcation of "reckonable" law to detectable facts: Parties who share a foresight that judgment will soon be rendered on the law and facts settle. As the legal process is made less decisive and less predictable, private settlement is inpeded by differences in the forecasts being inade by the adversaries. ${ }^{72}$ Mediation may sometines help

68. Richard S. Annold, Trial by Jury: The Constitutional Right to a Jury of Twelve in Civil Trials, 22 HOFSTRA L. REV. 1, 24-35 (1993); Paul D. Carrington, The Seventh Amendment: Some Bicentennial Reflections, 1990 U. CHI. LEGAL. F. 33, 51-56; see also George L. Priest, The Role of the Civil Jury in a System of Private Litigation, 1990 U. CHI. LEGAL F. 161. The Civil Rules Committee has published for public comment a proposal to restore the 12-member jury.

69. See Linda Silberman, Judicial Adjuncts Revisited: The Proliferation of Ad Hoc Procedure, 137 U. PA. L. REV. 2131, 2131-32, 2174 (1989) (discussing the increased use of masters, magistrates, and arbitrators).

70. Daniel R. Coquillette et al., The Role of Local Rules, 75 A.B.A. J. 62 (1989); John P. Frank, Local Rules, 137 U. PA. L. REv. 2059, 2060 (1989); Stepheu N. Subrin, Federal Rules, Local Rules and State Rules: Uniformity, Divergence and Emerging Procedural Patterns, 137 U. PA. L. Rev. 1999, 2000-01 (1989); Carl Tobias, More Modern Civil Process, 56 U. PITT. L. ReV. 801, 812 (1995).

71. Resnik, supra note 56, at 494. Charles Alan Wright's tern is "malaise." Charles A. Wright, Foreword: The Malaise of Federal Rulemaking, 14 REv. LITIG. 1, 1 (1994).

72. George L. Priest \& Benjamin Klein, The Selection of Cases for Trial, $13 \mathrm{~J}$. LEGAL STUD. 1, 4 (1986). 
to diminish those differences, but mediators can build their bridges only so far.

All these things considered, the office of the U.S. District Judge is strikingly different from the office held by his or her predecessors only three decades ago. The conscious mission of inany district judges is less to make decisions applying law to the facts, and more to preside over the manufacture of dispositions. The primary judicial labor is not trial, but conferring with lawyers and staff. $^{73}$ District courts' results are evaluated less rigorously than once they were by the courts of appeals, but more rigorously by the Administrative Office of the U.S. Courts. ${ }^{74}$ The courts of appeals are increasingly reinote and less known to the judges whose work they review, ${ }^{75}$ and hence less a presence in the daily routine and work of district judges. District judges have thus steadily gained discretion and individual power at the expense of the authority of circuit judges. The Supreme Court of the United States is increasingly like Tolstoy's generals, ${ }^{76}$ who uttered coinnrands obsolete by the time given, erratically transmitted down the chain of command, and infrequently obeyed. Partly because of the increase in their unreviewed discretion, district judges have at the saine time gained power over individual civil litigants and their counsel. In short, the district judge is each year less a judge of a law court and inore a local chancellor or lord of the manor, inore to be feared and less to be respected.

I will not burden the reader with my attempt to understand all the causes of this devolution. Like mucli social change, it is the product of a march of events to wlich there is no luman drummer. The causes of those events are numerous and complex. Many are associated with growth in the size of the courts unaccoinpanied

73. Resnik, supra note 62 , at 380 .

74. Robel, supra note 61 , at 3.

75. See Yeazell, supra note 53, at 643-44; An Unknown Court, supra note 55, at 209; see also Arthur D. Hellman, Jumboism and Jurisprudence: The Theory and Practice of Preccdent in the Large Appellate Court, 56 U. CHI. L. REV. 541 (1989).

76.

[I]t was not Napoleon who directed the course of the battle, for none of his orders were executed and during the battle he did not know what was going on before him. ... [The battle] occurred independently of him, in accord with the will of hundreds of thousands of people who took part in the common action. It only seemed to Napoleon that it all took place by his will.

LeO TOLSTOY, WAR AND PEACE 876 (Aylmer Maude \& Louise Maude trans., Simon \& Schuster 1942) (1865). For an elaboration of this concern, see Relationships in the Future, supra note 55 , at 76 . 
by modifications needed if the legislative purposes of 1891 and 1934 were to be preserved. An odd feature is that the devolution has occurred during a time of rising expectations of rights, or increasing "rights talk" as Mary Ann Glendon would have it; ${ }^{7}$ thus, unlike most adaptations in legal and political institutions, this one has cut against the grain of the culture of which it is a part.

\section{PROCEDURAL LOCALISM}

In reversing the ancient tradition of locahisin in federal civil procedure, the rulemakers of 1938 did not attempt to standardize all aspects of federal civil practice. The Rules did not deal at all with admission to the bar of the district courts, or with the discipline of lawyers. ${ }^{78}$ On that account, Rule 83 authorized the making of local rules "not inconsistent" with the national rules. It was expected that the Rule "would [otherwise] be used only on rare occasions when the Civil Rules dehiberately had left gaps to be filled in the hight of recognized local needs[, such as the setting of motion days].".79

Within the range of inatters addressed by the Rules, abundant provision was inade for the exercise of prudent discretion by the trial judge. ${ }^{80}$ It was the aim of the draftsinen to guide the district courts, but not so to restrict them with procedural requirements that judgments would be rendered on the basis of procedural miscues rather than substantive merits. ${ }^{81}$ Simphicity in the adjective law was an important aim. ${ }^{82}$ The broad command of the

77. MaRy ANN Glendon, Rights Talk (1992).

78. Whether disciplinary practices should vary from one district to another remains a mooted question. See Amy R. Mashburn, A Clockwork Orange Approach to Legal Ethics: A Conflicts Perspective on the Regulation of Lawyers by Federal Courts, 8 GEO. J. LEGAL ETHICS 473, 473 (1995). This matter is now on the agenda of the Standing Committee on Rules of the Judicial Conference.

79. See 2 Charles A. Wright \& ARthur R. Miller, Federal Practice and PROCEDURE § 3152 (1990).

80. See Maurice Rosenberg, Judicial Discretion of the Trial Court, Viewed from Above, 22 SYRACUSE L. REV. 635, 655 (1971).

81. See Charles E. Clark, The Handmaid of Justice, 23 WASH. U. L.Q. 297, 319 (1938); see also Judith Resnik, Housekeeping: The Nature and Allocation of Work in Federal Trial Courts, 24 GA. L. REv. 909, 953-55 (1990). But see David M. Trubek, The Handmaiden's Revenge: On Reading and Using the Newer Sociology of Civil Procedure, LAW \& CONTEMP. PROBS., Autumn 1988, at 111, 117.

82. Janice Toran, 'Tis A Gift to Be Simple: Aesthetics and Procedural Reform, 89 MrCH. L. REv. 352 (1990); see also Stephen N. Subrin, Charles E. Clark and His Procedural Outlook: The Disciplined Champion of Undisciplined Rules, in JUDGE CHARLES 
Rules to the district judges was to decide cases on the law and the facts, with minimal preoccupation with procedural niceties such as those making sport of nineteenth century and earlier civil practice. A paradigmatic rule was Rule 52, which provided that a court of appeals may reverse a trial court's finding of fact only if it is "clearly erroneous"; the beauty of this rule is that it leaves little rooin for argument about procedure and directs the court to address the substantive merits at issue. ${ }^{83}$

Because the Rules favored procedural discretion as a means to achieve substantive accuracy, it was expected that litigation would proceed somewhat differently fronı one case to the next according to the needs of the situation; a necessary consequence of this flexibility was that the process would also differ from one federal courtroom to another, according to the tastes, instincts, and talents of individual judges. There was not in the 1938 Rules any notion that one size fits all; uniformity was an aspiration, not an overriding concern. ${ }^{84}$ But no one associated with the reforms of the 1930 s envisioned that there would be differences in procedure from one judicial district to the next; im that sense, it is accurate to say that the 1934 Act envisioned "hierarchically dictated uniformity." 85

There were in 1938, as now, differences amongst the ninetyfour federal districts. ${ }^{86}$ The "productivity" of some judges or groups of judges is greater than that of others. The civility of lawyers is greater ni sonie communities than others. The willingness and ability of hitigants to spend one another into oblivion is greater nil some places than others. Yet the primary task of each

EDWARD CLARK 115, 134 (Peninah Petruck ed., 1991). Maurice Rosenberg was perhaps the most recent member of the Advisory Committee on Civil Rules who was an active champion of this value. He urged that for every word added to the Civil Rules, a word should be deleted. The Rosenberg rule was observed in the 1991 amendments to the Rules, but was paid little heed in the 1993 round. Alas, complexity has a bright future.

83. See Edward H. Cooper, Civil Rule 52(a): Rationing and Rationalizing the Resources of Appellate Review, 63 NOTRE DAME L. REV. 645, 645-46 (1988); Martin B. Louis, Adjudicative Decision-Making Authority Between the Trial and Appellate Levels: $A$ Unified View of the Scope of Review, the Judge/Jury Question, and Procedural Discretion, 64 N.C. L. REV. 993 (1986).

84. See Shapiro, supra note 65 , at $1973,1993-94$.

85. Yeazell, supra note 53, at 672-73 n.134; cf. Counter-Reformation, supra note 12 , at 401 (arguing that in the CJRA, Congress sought to confer rulemaking power on local citizens' groups).

86. Carl Tobias, Civil Justice Reform and the Balkanization of Civil Procedure, 24 ARIZ. ST. L.J. 1393, 1413 (1992). 
federal court is essentially the same in all districts, and the differences among them seldoin suggest reasons for material differences in the procedure employed in different districts. ${ }^{87}$ There was and is no good reason why the rules of pleading should be different from one district to the next; the same is also true for rules governing the manner of serving process, the number or length of depositions, the scope of the lawyers' subpoena power, the number of jurors or the manner of their selection, the evidence admissible at trial, the form and content required of summary judgment motions, or other matters addressed in the Civil Rules. One wishing to confirm this might review a randomly selected score of the ninety-four local plans promulgated under the CJRA or the preexisting local rules; while there are differences in the plans and local rule sets, those differences seldom, if ever, reflect variations in local conditions. What they reflect are differences in the styles and values of particular groups of judges. The features of the local cost and delay reduction plan at issue in Friends of the Earth, for example, have nothing to do with local conditions in the federal courthouses of Eastern Texas, and everything to do with the temperaments of a particular group of judges and their estmration of events and relations found outside the court. Likewise there are no differences in local conditions to explain local rules "determining the balance between 'free press' and 'fair trial' concerns, dismissing cases for failure to prosecute and interrogating jurors after verdict." 88 As Geoffrey Hazard has said, "[L]ocal rules can best be described as measurements of the chancellors' feet." ${ }^{\prime 89}$ In this respect, national uniformity as a brake on locahsm is a safeguard against "the tyranny . . . of willful renegades." 90

There are housekeeping matters that vary froin one district to the next; inany such matters are considered to be too trivial to be the subject of a national rule to which obedience is commanded by the Supreme Court. ${ }^{91}$ If, however, a matter is too trivial to be

87. Counter-Reformation, supra note 12, at 380; Lauren K. Robel, Fractured Procedure: The Civil Justice Reform Act of 1990, 46 STAN. L. REV. 1447, 1483-84 (1994).

88. Steven Flanders, Local Rules in Federal District Courts: Usurpation, Legislation, or Information?, 14 LOY. L.A. L. REV. 213, 219 (1981) (footnotes omitted).

89. Hazard, supra note 52, at 1286.

90. Robert E. Keeton, The Function of Local Rules and the Tension with Uniformity, 50 U. PITr. L. REV. 853, 860 (1989); see also John P. Frank, Local Rules, 137 U. PA. L. REV. 2059, 2060 (1989) (describing local rules as "the product of sheer arrogance and irresponsibility").

91. See Flanders, supra note 88, at 261-69; Steven Flanders, In Praise of Local Rules, 
in a national rule, it is not clear why it should be the subject of any "rule" at all. In part, this is a matter of nomenclature: "Local rules" often include matters that the court uttering thein does not expect to enforce judicially. For example, if the clerk's filing cabinets are built for eleven-inch paper, lawyers and parties inust be informed that fourteen-mch documents may not be filed, and must be done over on shorter pages. ${ }^{92}$ However, transmissions of such "local knowledge" ne3 need not take the form of a command; they take that forın chiefly because courts are accustomed to speakmg only in the imperative voice. Local rules dealing with housekeeping in the clerk's offices are therefore dispensable. ${ }^{94}$

Indeed, it is not clear why some of the housekeeping practices that are the subject of local rules should be different from one district to the next. What purpose is served if filing cabimets of different sizes are used in different federal courthouses? The absence of an answer to such questions is the source of the new and arguably oxymoromic concept of the "umiforn local rule." For some purposes, what may be needed is a standard operating manual available to anyone dealing with federal clerks of court; such a manual need not be written in the imperative voice of rules, yet would serve to ease the task of the stranger appearing for the first time in a particular federal courthouse.

While there are no visible benefits to most local rules, their vices are obvious. Local rulemaking dealing with matters that are also the subject of national rules is $\mathrm{m}$ alnost every instance at odds with the primary aims of the Rules Enabling Act. Localisin creates legal clutter - that is, background noise making it harder to hear important commands expressed in rules that will be enforced by appellate courts. Legal clutter is the eneiny of simplicity; the more such material is placed in the hands of parties and lawyers, the more billable hours will be expended, but the less well read

62 JUdiCATURE 28, 30-31 (1978).

92. It does not follow, of course, that the clerk's office needs the power to refuse to accept as timely a filing that is on paper of the wrong size. See advisory committee's notes to the 1991 amendment to FED. R. CIV. P. 5.

93. See generally CLIFFORD GEeRTZ, LOCAL KNOWLEDGE: FURTHER ESSAYS IN INTERPRETATIVE ANTHROPOLOGY (1983) (describing general issues from different local perspectives).

94. Cf. Erwin Chemerinsky \& Barry Friedman, The Fragmentation of Federal Rules, 46 MERCER L. REv. 757 (1995) (positing that the proliferation of local rules creates problems in the management of civil litigation). 
and well understood the real rules will be, and the more likely that litigation will digress from the merits to satellite controversies. ${ }^{95}$ Legal clutter will be diminished by a new provision in Rule 83 taking effect in 1995, which protects parties from suffering a loss of substantial rights for nonwillful violation of a local rule, but this provision will not stem the flow of new clutter issuing forth under the auspices of the CJRA.

Sucl legal clutter gives undue advantage to cognoscenti. Normally, these will be local lawyers who are given an advantage over counsel froin other districts. But clutter also favors the expert litigator over the lawyer inaking episodic appearances in court. The 1934 Rules Enabling Act was at pains to reduce such advantages. ${ }^{97}$ As clutter increases, the cost of legal services is also increased by a diminution of competition and retention of redundant counsel.

Theoretically, elaborate local rules and plans could also impede the objective of the national rules to confer discretion in individual district judges that they might decide cases on their inerits. This would be so if local rules were rigorously enforced to cabin the discretion of district judges who are out of step with their colleagnes on the saine bench. I have, lowever, been unable to find a single case in which a judgment was reversed because a district judge disregarded a local rule; a characteristic of local rules, as distinct from national rules, is that those who make them liave no means to compel compliance. In contrast, there are numerous cases in which judgments have been reversed on appeal on the ground that the enforcement of a local rule resulted in injustice too great to be tolerated..$^{98}$ At least two circuits have de-

95. John P. Frank made this point in other terms in JoHN P. FRANK, AMERICAN LAW: THE CASE FOR RADICAL REFORM 86-90 (1969). For a recent elaboration of this concern, see Myron J. Bromberg \& Jonathan M. Kom, Individual Judges' Practices: An Inadvertent Subversion of the Federal Rules of Civil Procedure, 68 ST. JOHN's L. REV. 1, 5-7 (1994).

96. "A local rule imposing a requirement of form shall not be enforced in a manner that causes a party to lose rights because of a nonwillful failure to comply with the requirement." FED. R. CIV. P. 83(a)(2).

97. Senator Thomas Walsh powerfully resisted enactment of the Rules Enabling Act for this reason. He mistrusted the American Bar Association as elitist and favored "the one hundred who stay at home as against the one who goes abroad." Burbank, supra note 39, at 1064 (citation ounitted).

98. E.g., World Thrust Films, Inc. v. International Family Entertainment, Inc., 41 F.3d 1454, 1456-57 (11th Cir. 1995) (S.D. Fla. R. 16.1); Zambrano v. City of Tustin, 885 F.2d 1473, 1480 (9th Cir. 1989) (C.D. Cal. R. 2.1); United States v. Moradi, 673 F.2d 
clared that they will not sustain a dismissal for mere failure to comply with a local rule. ${ }^{99}$ Friends of the Earth is one among a number of cases in which individual judges have found reason not to apply seemingly apphicable local rules. ${ }^{100}$ Perhaps a judge who was notoriously defiant of a local rule would attract the use of the supervisory power of the courts of appeals, ${ }^{101}$ but I have been unable to imagine a local rule that would warrant the use of such extraordinary appellate jurisdiction.

Consideration of the problem of securing compliance with local rules by individual judges suggests the wisdom of the 1938 approach to procedural discretion. The realists who wrote the 1938 Rules recognized that judges, especially Article III judges, can be compelled to conform to the purposes of procedural rules only if the rules are cast in indeterminate language expressing elastic principles, leaving it to appellate review to control judicial behavior departing from the broad pattern fixed by their proposed Rules. "Tight will tear; Wide will wear"102 was the sartorial wisdom applied by the draftsmen who looped to effectively contain and direct judicial discretion by broadeuing the channel in whicl it runs. ${ }^{103}$ Those who have since participated in amending the rules have sometimes practiced another homely wisdom, that of putting sidewalks where the people have made paths. ${ }^{104}$

Despite its shortfall in benefits, localism in federal procedural matters has had something of the tenacity of original sin. Localism, as Charles Alan Wright said in 1966, is the "'soft underbelly' of federal procedure. ${ }^{105}$ In the decade beginning in 1938, there was

725, 728 (4th Cir. 1982).

99. Hargrett v. Pledger, No. 94-3289, 1995 U.S. App. LEXIS 8890, at *2 (8th Cir. Apr. 19, 1995); Carver v. Bunch, 946 F.2d 451, 454-55 (6th Cir. 1991); Johnson v. BoydRichardson Co., 650 F.2d 147, 149 (8th Cir. 1981).

100. E.g., Manshack v. Southwestern Elec. Power Co., 915 F.2d 172 (5th Cir. 1990).

101. Cf. La Buy v. Howes Leather Co., 352 U.S. 249, 259-60 (1957) (finding that supervisory control of the district courts is necessary to proper judicial administratiou); Thiel v. Southern Pac. Co., 328 U.S. 217, 225 (1946) (reversing the trial court based on the Court's power of supervision over the administration of justice).

102. Francis lieber, Legal and Polmitical Hermeneutics 195 n.6 (William G. Hammond ed., 3d ed. 1880).

103. This feature seems to be a demerit in the minds of some contemporary observers who may fancy that district courts could be made to enter correct judgments if only the procedural rules were drawn tightly enough. See Stephen B. Burbank, Of Rules and Discretion: The Supreme Courh, Federal Rules and Common Law, 63 NOTRE DAME L. REv. 693, 715-16 (1988); Subrin, supra note 21, at 992-1002.

104. See Shapiro, supra note 65, at 1992.

105. Comment, The Local Rules of Civil Procedure in the Federal District Courts-A 
a visible reluctance of some district judges to obey the rules, especially Rule 8, which declared that a plam, simple statement of a claim was sufficient to withstand an attack on pleadings. That rule was a well-considered effort to terminate the wasteful investment of time and judicial energy in bickering over the sufficiencies of parties' pleadings. ${ }^{106}$ To this day, federal judges have contmued to defy Rule $8,{ }^{107}$ to the distress of the courts of appeals ${ }^{108}$ and of the Supreme Court, which found occasion again in 1993 to say that Rule 8 means what it says. ${ }^{109}$ Sometimes district courts have expressed their preferences in these matters through local rules imposing elevated pleading requirements on particular classes of cases. ${ }^{110}$

With respect to this endemic localism, the Supreme Court of the United States made an epic blunder in 1972 when it held that the two district judges in Montana could by local rule reduce the size of juries in their court from twelve to six. ${ }^{111}$ The local rule in that case was at odds with Rule 48 of the Federal Rules of Civil Procedure then in force, ${ }^{112}$ violated the cautionary language of the Rules Enabling Act; ${ }^{113}$ and without apparent thought, doubled the effect of the peremptory challenges provided in the Judicial Code ${ }^{114}$ and arguably violated the Seventh Amendment. ${ }^{115}$

Survey, 1966 Duke L.J. 1011, 1012 (quoting Letter from Professor Charles A. Wright to the Duke Law Journal (Nov. 16, 1965)); see also 12 CHARLES A. WRIGHT \& ARTHUR R. Miller, Federal PRACTICE AND PROCEDURE § 3152 (1973 \& Supp. 1994).

106. Charles E. Clark, Simplified Pleading, 27 IOWA L. REv. 272, 279-82 (1942).

107. See Richard L. Marcus, The Revival of Fact Pleading Under the Federal Rules of Civil Procedure, 86 Colum. L. REv. 433, 436 (1986) ("[F]ederal courts are insisting on detailed allegations more and more often, particularly in securities fraud and civil rights cases.").

108. See e.g., Cook \& Nichol, Inc. v. Plimsoll Club, 451 F.2d 505, 506-07 (5th Cir. 1971).

109. Leatherman v. Tarrant County Narcotics Intelligence and Coordination Unit, 507 U.S. 163 (1993).

110. See e.g., S.D. Ga. Local Rule 9.1; S.D. W. VA. Local Rule 8.

111. Colgrove v. Battin, 413 U.S. 149, 151 (1972).

112. Rule 48 then authorized juries of less than 12 by agreement of the parties. Rule 47 also assumed a jury of a fixed size of $12 \mathrm{~m}$ establishing a method for selecting alternate jurors-a system qnite useless if the jury can be less than 12. FED. R. CIV. P. 47, 48 advisory committee's note.

113. The 1934 Act contained the following proviso: "[t]hat in such union of rules the right of trial by jury as at common law ... shall be preserved to the parties inviolate." 48 Stat. 1064 (1934).

114. Jury Selection and Service Act of 1968, Pub. L. No. 90-274, 82 Stat. 53 (codified as amended at 28 U.S.C. $\$ \S 1861-1869$ (1994)). See generally JON M. VAN DYKE, JURY SELECTION PROCEDURES 145-60, 166-69 (1977).

115. See generally Paul D. Carrington, The Seventh Amendment: Some Bicentennial Re- 
Because the Court could tolerate a rule as innovative as that invoked in Montana, the sky seemed to be the limit of local rulemaking power.

By the mid-1980s, the legal clutter created by local rules had becoine an impediment to the practice of law, a source of cost and delay, and a significant trap for the unwary. ${ }^{116}$ Some local rules were redundant to the national rules; some were paraphrases of national rules; some were in conflict with national rules; and in many districts, it was not easy to know what the current local rules were. Some district courts purported to vest a power of enforcement in the clerk of court, so that one way to discover a local rule was to have the clerk refuse an instrument for filing. ${ }^{117}$ In response to widespread complaints at the bar and in Congress, the Judicial Conference of the United States established that the Standing Committee would prepare a plan amed at reducing the growing mass of rules. ${ }^{118}$ And the Judicial Improveinents Act of $1988^{119}$ revised the 1934 Rules Enabling Act for the purpose of stemming the tide of proliferating localism. ${ }^{120}$ Specifically, the Act required local rules to undergo the scrutiny of the judicial councils of the relevant circuits ${ }^{121}$ and re-established the requirement that local rules be affirmatively consistent with national

flections, 1990 U. CHI. LEGAL F. 33.

116. JACK B. WEINSTEIN, REFORM OF COURT RULE-MAKING PROCEDURES 117-37 (1977); David M. Roberts, The Myth of Uniformity in Federal Civil Procedure: Federal Civil Rule 83 and District Court Rulemaking Powers, 8 U. PUGET SOUND L. REV. 537, 540 (1985). For earlier reviews of the emerging problem, see WRIGHT \& MILLER, supra note 105, at 217; see also Note, Rule 83 and the Local Federal Rules, 67 ColuM. L. Rev. 1251, 1259-63 (1967); The Local Rules of Civil Procedure in the Federal District Courts-A Survey, supra note 105, at 1012.

117. Janet Napolitano, A Comment on Federal Rules, Local Rules, and State Rules: Uniformity, Divergence and Emerging Procedural Patterns, 137 U. PA. L. REv. 2063, 2063 (1989) (commenting on article by Stephen N. Subrin in same issue). "Only a party who lias been sent away from the clerk's office without being allowed to file a complaint on the last possible day because it was punclied with two holes, not three, can fully appreciate the imjustice that supposedly berign local rules can cause." Id; cf. Loya v. Desert Sands Unified Scliool Dist., 721 F.2d 279, 280-81 (9th Cir. 1983) (reversing the dismissal of a complaint filed just before expiration of the statute of limitations on the wrong size paper).

118. ADMINISTRATIVE OFFICE OF THE U.S. COURTS, REPORT OF THE PROCEEDINGS OF THE JUDICIAL CONFERENCE OF THE UNITED STATES 67 (1984).

119. 28 U.S.C. \& 2071(b) (1988).

120. H.R. Rep. No. 889, 100th Cong., 2d Sess. 28 (1988), reprimted in 1988 U.S.C.C.A.N. 5982, 5989.

121. 28 U.S.C. $\& 2071(c)(1)$. 
rules, ${ }^{122}$ a provision effectively superseding Rule 83 which contained the double-negative requirement that local rules be "not inconsistent" with national rules. The 1988 legislation remains the law, and an amendment to Rule 83 to conform it to the 1988 Act became effective December $1,1995 .^{123}$

\section{THE CIVIL JUSTICE REFORM ACT}

On the heels of the 1988 legislation came the Civil Justice Reform Act of 1990, from which Friends of the Earth claims to derive authority for its deviant local plan. The origins and legislative history of that Act have been adequately recounted elsewhere ${ }^{124}$ but a brief review seems required as a predicate to my extended argument regarding the Act's meaning. It was virtually the sole handiwork of Senator Joseph Biden, then the chair of the Senate Judiciary Committee. Precisely what aroused the Senator's interest in civil procedure is uncertain, ${ }^{125}$ but the level of that interest was suddenly elevated in 1989.

The Senator was mindful of two decades of grumbling about alleged discovery abuse. ${ }^{126}$ The allegations had been much studied; there was a problem, but a much smaller one than some supposed. Discovery was seldoin abused in cases involving smaller stakes, or by lawyers working for contingent fees. Abuse was

122. See 28 U.S.C. \& 2071(a) ("Such rules shall be consistent with Acts of Congress and rules of practice and procedure prescribed under section 2072 of this title.").

123. The proposal was sent to the Supreme Court in 1993, 114 S. Ct. 397, 417-18 (1993), and was promulgated by the Court on April 27, 1995, 115 S. Ct. 643, 646 (1995).

124. See generally Counter-Reformation, supra note 12, at 375-407; Robel supra note 87 , at $1450-54$.

125. The Senator's general aims are explained in Joseph R. Biden, Equal Accessible, Affordable Justice Under Law: The Civil Justice Reform Act of 1990, 1 CORNELL J. LAW \& PUB. POL'Y 1 (1992).

126. See generally Frank L. Flegal \& Steven M. Umin, Curbing Discovery Abuse in Civil Litigation: We're Not There Yet, 1981 B.Y.U. L. REv. 597 (reviewing the discovery reform that has taken place since 1976 and assessing the need for further change); Vices, supra note 63 (arguing for a trans-substantive approach to procedural reform); Thomas M. Mengler, Eliminating Abusive Discovery Through Disclosure: Is It Again Time for Reform?, 138 F.R.D. 155 (1991) (recommending greater resource allocation to curb discovery abuse rather than continued rule revision); Linda S. Mullenix, Discovery in Disarray: The Pervasive Myth of Pervasive Discovery Abuse and the Consequences for Unfounded Rulemaking, 46 STAN. L. REv. 1393 (1994) (examining the myths of discovery abuse and how they have informed the civil justice reform efforts of the early 1990s); Maurice Rosenberg, Curbing Discovery Abuse in Civil Litigation: Enough is Enough, 1981 B.Y.U. L. REV. 579 (critiquing the rule changes proposed by the ABA's special committee and examining alternatives). 
found in a limited number of larger cases in which lawyers, in an excess of adversary zeal, sometiunes used discovery devices to harass and burden their opponents. ${ }^{127}$ The problein was thus in part one of professional ethics. ${ }^{128}$ Among the causes of the problem were exponential growth in the quantity of documentary records awaiting discovery, the perhaps improvident acceptance in the 1940 s and 1950s by chents of the practice of paying lawyers by the hour, the professional misconduct of soine lawyers bilking their chents by milking their cases, ${ }^{129}$ a tendency of corporate managers to postpone hard decisions or leave thein for their successors while paying large fees to lawyers to keep litigation going, and lieightened prosperity enabling inany businesses to lire lawyers to engage in misuse of discovery.

There was also some complaining about the general cost of civil litigation of which the Senator was likely aware, but much of it may liave been a response to the discovery problem. ${ }^{130}$ No one lias yet atteinpted to analyze or even to depict other excessive costs. It is, however, a fact that civil trials in federal courts have been growing longer, and thus inore expensive. While the median

127. See Paul R. Connaliy et al., Judicial Controls and The Civil lmigaTION PROCEsS: DisCovery (1978); DANIEL SEgel, SURVEY OF THE LITERATURE ON DISCOVERY FROM 1970 TO THE PRESENT: EXPRESSED DISSATISFACTIONS AND PREFERRED REFORMS 10-11 (1978); JOHN SHAPARD \& CARROLL SERON, FEDERAL JUdICIAL CENTER, ATTORNEYS' VIEWS OF LOCAL RULES LIMITING INTERROGATORIES (1986). See generally Wayne D. Brazil, Civil Discovery: Lawyers' Views of Its Effectiveness, Its Principal Problems and Abuses, 1980 AM. B. Found. REs. J. 787 (1980) (discussing litigators assessment of discovery system and arguing that mucl of the abuse of the discovery process occurs in larger cases); Wayne D. Brazil, The Adversary Character of Civil Discovery: A Critique and Proposals for Change, 31 VAND. L. REv. 1295 (1978) [hereinafter Civil Discovery] (discussing how the adversarial nature undermines the purpose of the discovery process, contributing significantly to the cost of litigation); Maurice Rosenberg, Sanctions to Effectuate Pretrial Discovery, 58 ColuM. L. REv. 480 (1958) (recommending effective discovery sanctions to curb abuse).

128. Robert W. Gordon \& William H. Simon, The Redemption of Professionalism?, in Lawyers, "Ideals/ LaWyers," Practices: TRANSFormations IN the AMERICAN LEGAL PROfEssion 230, 241 (Robert L. Nelson et al. eds., 1992) (discussing briefiy the interface between professional ethics and discovery abuse).

129. Civil Discovery, supra note 127, at 1314-15 (discussing economic temptation of lawyers being paid by the hour to protract and complicate discovery); William W. Schwarzer, The Federal Rules, the Adversary Process, and Discovery Reform, 50 U. PITT. L REV. 703, 710 (1989) (discussing attorney self-interest resulting in over-discovery so long as clients will pay or costs can be imposed on the opposing losing party).

130. See, e.g., Order Amending the Fed. Rules of Civil Procedure, 446 U.S. 997, $1000-01$ (1980) (Powell, J., dissenting from the promulgation of the 1980 amendinents to the Rules). 
length of a trial was one day in 1950, it is now at least twice that, and many more federal civil trials now occupy a week or longer of the court's time. ${ }^{131}$ This in part reflects a change in the subject matter of the civil docket in federal courts, but another likely cause of this increase has been the use of opimion testimony that sometimes adds substantial complexity to matters in dispute. ${ }^{132} \mathrm{~A}$ whole new industry has been created smce 1970 to soak up billions of dollars of expenses incurred in the compensated time of the experts and the lawyers who prepare and examme them. Whetlier this profligate use of opimon testimony has enhanced the quality of decisions has seldom been examined, ${ }^{133}$ it is a question I am not prepared to address here. Despite the development of this costly practice, the meager empirical evidence suggests that there had been little, if any, increase in the real cost of most litigation. ${ }^{134}$ Perliaps for that reason, the CJRA did not address the problem of the length of trials or the excessive use of opinion testimony.

The law's delay is a problem endemic to all systems of dispute resolution. ${ }^{135}$ Disputants have long complained of it, probably since the time of Hammurabi. ${ }^{136}$ Measured by the elapsed

131. Compare Judicial Conference of THE UNITEd STATES, 1950 ANNUAL REPORT 164 [hereinafter 1950 ANNUAL REPORT] (listing the length of civil and criminal trials completed in 86 U.S. District Courts during the fiscal year ending June 30, 1950) with JUDICIAL CONFERENCE OF THE UNITED STATES, 1992 ANNUAL REPORT 217 [hereinafter 1992 ANNUAL REPORT] (The comparison suggests that the percentage of trials of 10 days or longer quadrupled froin $1 \%$ to almost $4 \%$.).

132. See Anthony Champaign et al., Expert Witnesses in the Courts: an Empirical Examination, 76 JUDICATURE 5 (1992).

133. See Deborah Hensler, Science in the Court: Is There a Role for Alternative Dispute Resolution?, LAW \& CONTEMP. PROBS., Summer 1991, at 171 (1991) (considering whether and how ADR can contribute to the improvenent of court procedures dealing with scientific questions); Peter Huber, Medical Experts and the Ghost of Galileo, LAw \& CONTEMP. PROBS., Summer 1991, at 119 (1991) (discussing the historical use and effect of expert witnesses in cancer and cerebral palsy cases).

134. See generally David M. Trubek et al., The Costs of Ordinary Litigation, 31 U.C.L.A. L. Rev. 72 (1983) (presenting a national study of federal and state courts of hitigation expenditures).

135. See George L. Priest, Private Litigants and the Court Congestion Problem, 69 B.U. L. REV. 527, 527 (1989). See generally HANS ZEISEL ET AL, DELAY IN THE CoURT 19-24 (1959) (discussing the history of court congestion).

-136. "[I]n the third millennium before Christ men were coinplaining about the inefficiency of legal procedure, and I fancy that if any of you are destined in the year 7000 A.D. to revisit ... you will be obhiged to report ... that mankind still exhibits the same discontentment with its methods of adjusting human differences . . . " LEARNED HAND, THE DEFICIENCIES OF TRIALS TO REACH THE HEART OF THE MATTER (1921) 
median time between the jomder of issue and the date of trial, delay in the federal courts has significantly mcreased since 1950 (when it may have been at an all-time low), but most of the increase in delay occurred before $1970 .{ }^{137}$ Moreover, the elapsed time between filing of an action and disposition has diminished nnarkedly, perhaps as a result of more managerial judging that pushes parties to settle. ${ }^{138}$ The problem of delay is not evenly distributed among the ninety-four districts. At least one district, the Eastern District of Virgima, has achieved a reputation for its "rocket docket" that disposes of all civil cases with remarkable dispatch, ${ }^{139}$ whether at some possible cost to the quality of its dispositions, I do not know. On the other hand, some districts most heavily affected by the war on drugs may have difficulty in finding time to try civil cases. That seems the most likely cause for the longer delay in getting civil cases to trial. There is also an exponential increase in civil actions brought by prisoners against the corrections systems reflecting in part the exponential increase in the number of Americans in prison, $;{ }^{140}$ while these cases seldoin result in trial, they make exigent demands on the time of the

reprinted in 3 ASSOCIATION OF THE BAR OF THE CITY OF NEW YORK, LECTURES ON LEGAL TOPICS 87,89 (1926).

137. In fiscal year 1950, the median elapsed time in getting to trial was 6.7 months. 1950 ANNUAL REPORT, supra note 131, at 156. In 1970, the period was 12 months. JUDICIAL CONFERENCE OF THE UNITED STATES, 1970 ANNUAL REPORT 260 [hereinafter 1970 ANNUAL REPORT]. In 1992, it was 15 months. 1992 ANNUAL REPORT, supra note 131, at 226.

138. In fiscal year 1950 , the median time from filing to disposition was 11.2 months. 1950 ANNUAL REPORT, supra note 131, at 152. In 1970, the period was 10 months. 1970 ANNUAL REPORT, supra note 137, at 245(i). In 1992, it was 8 months. 1992 ANNUAL REPORT, supra note 131, at 208.

139. See Quick Response to Defense's Causation Attack Pays Off for Plaintiff in Tylenol Case, INSIDE LITIGATION, December 1994, at 9.

140. Since 1988, the number of federal prisoners has donbled to about 100,000. FED. BUREaU OF PRISONS, U.S. DEP'T OF JUSTICE, STATE OF THE BUREAU 5 (1993). See generally BARBaRA S. VINCENT \& PAUL J. HOFER, FED. JUdICIAL CENTER, THE CONSEQUENCES OF MANDATORY MINIMUM PRISON TERMS: A SUMMARY OF RECENT FINDINGS (1994) (describing prison growth attributable to sentencing under the federal mandatory minimum sentencing statutes).

The Violent Crime Control and Law Enforcement Act of 1994, Pub. L. No. 103-322, 108 Stat. 1796 (1994), seems certain to double or triple the present number. Senate Crime Bill Will More Than Double American Prison Population by Year 2005, CORRECTIONS Digest, 1994, at 1-4; Peter J. Benekos \& Alido V. Merlo, Three Strikes and You're Out!: The Political Sentencing Game, 59 FEDERAL PROBATION, 1995, at 6-7. In California, similar provisions quadrupled the state prison population between 1980 and 1992. Id. 
federal judges. ${ }^{141}$ Overall, however, delay in U.S. District Courts is significant, but not critical; the civil dockets in many state courts are worse, ${ }^{142}$ as are the dockets of U.S. Courts of Appeals. ${ }^{143}$

In addition to expressions of grief about cost and delay, it also became fashionable to complain of "hyperlexis,"144 the excessive use of hitigation to solve problems. There are, it is true, nore filings of civil actions in federal courts per capita than there were three decades ago. The growth is at least im part a response to laws enacted by Congress, such as the statute at issue in Friends of the Court. ${ }^{145}$ It may also reflect economic conditions enabling more business firms to spend inore freely on litigation costs in routine contract disputes. ${ }^{146}$ It is also possible that some legislation lends itself to the assertion of unfounded claims; federal securities law may have been an exainple. ${ }^{147}$ It is also likely that the advent of lawyer advertising has elevated claim-consciousness and increased case filings in the personal injury field. And the use of the class action in mass tort cases, which entails the sending of notices that are essentially invitations to sue, has likely brought in some, and perhaps many, claims that would otherwise have been

141. In 1994, there were 57,940 prisoner petitions filed in all federal courts. 1994 ADMIN. OFFICE REPORT at A27. This constituted almost one-fourth of the civil filings, up from 43,195 and less than $20 \%$ in 1990 . Id. Less than $1 \%$ of these cases will result in trial. Id. at A36-37. It must be assumed that the number of prisoner petitions filed in federal court will very soon reach six figures.

142. See Marc Galanter, News from Nowhere! The Debased Debate on Civil Justice, 71 DENV. U. L. REV. 77 (1993) [hereinafter Debased Debate]; Marc Galanter, The Life and Times of the Big Six; or The Federal Courts Since the Good Old Days, 1988 WIs. L. REV. 921, 923 (1988); Counter-Reformation, supra note 12, at 396-407; see also TERENCE DUNGWORTH \& NICHOLAS M. PACE, STATISTICAL OVERVIEW OF CIVIL LITIGATION IN THE FEDERAL COURTS vii (1990) (arguing that the growth of civil litigation will not greatly lengthen the aggregate time to disposition in federal courts).

143. LONG RANGE PLAN FOR THE FEDERAL COURTS, supra note 57, at 9-13.

144. The term seems to have been invented by Bayless Manning, Hyperlexis: Our National Disease, 71 Nw. U. L. REv. 767, 767 (1977).

145. For an account of the many sources of the caseload increase, see RICHARD A. POSNER, THE FEDERAL COURTS: CRISIS AND REFORM 59-93 (1985); Wolf Heydebrand \& Carroll Seron, The Rising Demand for Court Services: A Structural Explanation of the Caseload of United States District Courts, 11 JuST. SYs. J. 303, 313-20 (1986).

146. Thomas B. Marvell, Civil Caseloads: The Impact of the Economy and Trial Judgeship Increases, 69 JUDICATURE 153, 153-54 (1985).

147. Janet C. Alexander, Do the Merits Matter? A Study of Settlements in Securities Class Actions, 43 STAN. L. REv. 497, 499-500 (1991). See also Roberta Romano, The Shareholder Suit: Litigation Without Foundation?, 7 J. L. ECON. \& ORG. 55, 55-56 (1991). If this were a problem, it may have been corrected by the 1995 amendments to the Securities Act. 
forsaken by the claimants. It is also possible that there has been some marginal decline in the moral constraints on the assertion of false claims. Senator Biden did not speak to this alleged problem of hyperlexis, but it was in the minds of many who have been leading critics of the legal system.

However, the complaint about hyperlexis, like the complaints regarding cost and delay, is seldom accompanied by empirical data. ${ }^{148}$ Anecdotal evidence of the alleged hyperlexis was, of course, not hard to come by; frivolous or hopeless claims abound now as before and cannot be rare im any legal system, as are hopeless defenses erected to gain for defendants the benefits of the law's delay. As early as 1815, Americans were accusing one another of bemg too contentious. One observer of that time explained:

The noble definition of law, that nothing is so high as to be above its reach or so low as to be beyond its care, is probably true to a greater practical extent in this country than in any other. The cause obviously is, not our liberty alone, but an alliance between an active and restless spirit of freedom and the comfortable condition of all classes of the community, not excepting, relatively considered, even the poor. This encourages and provokes the disposition to go to law by supplying it almost universally with the means. We have honest blacksmiths suing banks for false inprisonment, and street cleaners suing fine gentlemen for assaults and batteries as the common occurrences of our courts. ${ }^{149}$

All things considered, the chorus of complaint about civil procedure coming from "habitual defendants" appears to have been largely an expression of self-interest on the part of those who were losing lawsuits that they would have preferred to win. While there is no occasion for complacency im addressing such problems as the misuse of discovery and the profligate use of opimon testimony, neither was there cause for general alarm. It appears that Senator Biden was beguiled by a campaign of disinformation. ${ }^{150}$

148. See generally Richard D. Catenacci, Hyperlexis or Hyperbole: Subdividing the Landscape of Disputes and Defusing the Litigation Explosion, 8 REv. LITIG. 297 (1989) (reviewing the hiterature of excessive hitigiousness).

149. RICHARD RUSH, AMERICAN JURISPRUDENCE (1815), reprinted in THE LEGAL MIND IN AMERICA FROM INDEPENDENCE TO THE CIVIL WAR 44 (Perry Miller ed., 1962).

150. There is, however, little reason to beheve that CJRA has in fact benefited any 
One explanation of the initiative leading to his 1990 Act and the haste with which it was enacted is that it was a competitive response. ${ }^{151}$ Senator Biden nuay have been competing with Vice President Quayle's Competitiveness Council which advanced many similar diagnoses and prescriptions. ${ }^{152}$ The Quayle group did no more to identify the problen it sought to solve than did the Judiciary Committee. Nor was it any better equipped to identify those grievants who were so dissatisfied with the quality of civil justice in the federal courts. Nor did it have solutions likely to effect general reductions in the cost of civil litigation or in the time elapsing between filings and judgments. It did address the problem of profligacy in the use of opinion evidence, ${ }^{153}$ but these recomneendations have not found their way into legislative proposals. If it was possible to be more indifferent to einpirically deinonstrable reality than the Senate Judiciary Conumittee, Vice President Quayle achieved that feat with his famous broadside attack on trial lawyers. ${ }^{154}$ What may have been behind both initiatives, as well as soine of the propaganda about the deficiencies of civil justice in the federal courts, were the dissatisfactions of tort defendants, particularly defendants in products liability cases who were and are exposed by state tort law to risks of seemingly gigantic and arguably excessive liabilities, ${ }^{155}$ habilities to which some for-

corporate defendants who might have stimulated the Senator's interest. See D. Jeffrey Campbell \& Jonathan R. Kuhlman, Civil Justice Reform Act of 1990: An Experiment Gone Awry, 60 DEF. CoUns. J. 17 (1993)

151. See Lauren K. Robel, The Politics of Crisis in the Federal Courts, 7 Oнго ST. J. ON DISP. RESOL. 115, 115-16, 129-30 (1991) (arguing that the regulation was a response to an alleged crisis in the federal court system); Counter-Reformation, supra note 12, at 385-92.

152. See COUNCIL ON COMPETITIVENESS WORKING GROUP ON CIVIL JUSTICE REFORM, AGENDA FOR CIVIL JUSTICE REFORM IN AMERICA (1991) [hereinafter RECOMMENDATION]. Its recommendations were embodied in S. 2180, 102d Cong., 2d Sess. (1992). See also Exec. Order No. 12,778, 3 C.F.R. 359 (1991), reprinted in 28 U.S.C. § 519 (1994); Dan Quayle, Civil Justice Reform, 41 AM. U. L. REv. 559 (1992) (discussing proposals for reforming civil justice system). See generally Carl Tobias, Civil Justice Reform Roadmap, 142 F.R.D. 507 (1992) (charting developments in civil justice reform); Carl Tobias, Executive Branch Civil Justice Reform, 42 AM. U. L. REv. 1521 (1993) (discussing origin and development of civil justice reform).

153. RECOMMENDATION, supra note 152, at 12-14.

154. 1991 American Bar Association Annual Meeting (Aug. 11, 1991) (transcript available from Federal News Service).

155. Deborah $R$. Hensler concludes that the Council's proposals went well beyond procedural reform: "These proposals seek to change the current balance between individual plaintiffs and corporate defendants, in favor of the latter. That agenda is a political one, and it ought to be debated and decided on the floors of Congress and state 
eign competitors may not be exposed. This is the substance, if any exists, behind the smoke about hyperlexis, cost, delay, and competitiveness. ${ }^{156}$ But few, if any, pohiticians were ready to discuss tort reform in 1990 or 1992, and so the less threatening subject of civil procedure served as a surrogate. ${ }^{157}$ As Marc Galanter has amply demonstrated, the debate on civil justice reform was accordingly riddled with empirically falsifiable assumptions and assertions. ${ }^{158}$

Senator Biden began his efforts to confront the evils of cost and delay by securing the help of the Brookmgs Institution (Brookings). At his request, it examined the evils anew, largely disregardmg the studies cited here. It appears that the funds for the study came from a foundation run by a member of the Senator's staff, ${ }^{159}$ the source of its funds is unknown. A study group appointed by Brookings, from which sitting federal judges were excluded and im which representatives of business were mingled with a few representatives of other factions, ${ }^{160}$ met six times, with the Senator's staff serving as the staff of the study group to set its agenda. A Harris poll was conducted for the group; the poll, of course, could not measure cost or delay, but measured the impressions of cost and delay of some lawyers and judges. ${ }^{161}$ The Senator's staff then wrote a report, relying on the authority of the Harris poll as evidence of a problem to be remedied and disregarding the much harder data gathered by the Federal Judicial Center and other social scientists. ${ }^{162}$ The Brookings study group

legislatures." Deborah R. Hensler, Taking Aim at the American Legal System: The Council on Competitiveness's Agenda for Legal Reform, 75 JUDICATURE 244, 250 (1992).

156. Patrick Atiyah estimated that the total cost of tort claims in the United States is roughly 10 times that in the United Kingdom. Patrick S. Atiyah, Tort Law and the Alternatives: Some Anglo-American Comparisons, 1987 DUKE L.J. 1002, 1009-12.

157. Jack B. Weinstein, Procedural Reform as a Surrogate for Substantive Law Revision, 59 BROOK. L. REV. 827 (1993) (arguing that changes in substantive law have been camouflaged as procedural reforms); Carl Tobias, Silver Linings in Federal Civil Justice Reform, 59 BROOK. L. REV. 857 (1993) (noting the argument that political factors affected the enactment of reform).

158. Debased Debate, supra note 142; see also Robel, supra note 151, at 117 (discussing underlying assumptions in the debate).

159. Mark Gitenstein was the Senator's staff director and President of the Foundation for Change, Inc. The Brookings study may have been the only activity of the Foundation.

160. Counter-Reformation, supra note 12, at 389 n.42.

161. Louis HARRIS \& AsSOCIATES, INC., PROCEDURAL REFORM OF THE CIVIL JUSTICE SYSTEM: A STUDY CONDUCTED FOR THE FOUNDATION FOR CHANGE, INC. (1989).

162. BRookings INSTITUTION, JUSTICE FOR ALL: REDUCING COSTS AND DELAY IN Civil LITIGATION 6-7 (1989). 
did not again meet to discuss this report, but it was nevertheless published as a Brookings document. The Senator's staff then drafted a bill embodying ideas set forth in the report they had themselves written. The Judicial Conference of the Umited States was never consulted by the Brookings group or by the Senate staff, nor were any of the nnany organizations that routinely review the work of the Judicial Conference, such as the American Bar Association, the American College of Trial Lawyers, or even the Department of Justice. The Brookings report was little more than sinoke to screen the source of the Senator's initiative. ${ }^{163}$

A serious deficiency evident in both the Brookings report and the Senator's bill was the lack of a new solution to any problem they proposed to confront. As Patrick Johnson has observed, the bill did not reveal its objective with sufficient clarity to allow us to know when it might have been achieved; it was not clear, for example, how much delay should be reduced. ${ }^{164}$ Presumably, cases are not to be tried on the day they are filed, and presumably some cases will be ready sooner than others, but neither the report or the bill gave counsel about how soon is soon enough and not too soon.

The draft bill nevertheless proposed a system of "tracking" that aimed to assure firm, early trial dates in most cases. Experience seems to confirm that a fixed early trial date tends to prevent the metastisization of pretrial litigation and thus reduces cost; many federal judges were striving to fix early trial dates for that reason. Others, especially those afflicted with heavy criminal dockets, seemed to experience less success in holding to a schedule. The duty of federal courts to give preference to criminal cases ready for trial reflects the right of accused persons to a speedy trial, a right reconfirmed in Section 3162(a)(2) of the Criminal Code. ${ }^{165}$ When a civil trial is rescheduled to accommodate the criminal docket, the savings associated with firm scheduling is lost, and additional expense is often incurred.

163. Charles A. Wright generously describes the report as "particularly influential." Charles A. Wright, LAW OF FEDERAL Courts 436 (5th ed. 1994). However, its influence was preordained; causation went from the Senate to Brookings, not from Brookings to the Senate.

164. Patrick Johnston, Civil Justice Reform: Juggling Between Politics and Perfection, 62 FordHAM L. REV. 833, 849-55 (1994).

165. 18 U.S.C. $\S 3162(a)$ (1994). 
The draft also proposed requiring case management as a means of controlling discovery abuse. A growing number of federal judges were making imcreasing use of case management techniques entailing regular contact between the court and counsel as they prepared cases for settlement or trial. While individual judges have achieved soine reinarkable feats by means of case management, it is not certain that case management, as practiced by many judges, is truly an effective economy. ${ }^{166}$ It can absorb judicial energy and inake work for lawyers, especially when it does not function sinoothly, as happens in soine cases, and more frequently with soine judges. ${ }^{167}$

An odd feature of the Brookings-Biden initiative was its failure to take notice of the fact that the problems of civil justice were adversely affected by the huge increase in criminal litigation visited upon the federal courts in the decade previous to the enactment of the CJRA. It was also odd that an act entitled "Civil Justice" reflected concern for no aspect of justice other than its price and its timeliness, ${ }^{168}$ it seemed to assume that whatever was being done in the federal courts should and could be continued, but done faster and cheaper. It thus appears that Senator Biden and his Brookings supporters were annong those losing interest in the accuracy of the judgments rendered in federal courts.

The Judicial Conference protested; indeed, there was a chorus of objection from federal judges, although there were a few judicial supporters of the bill, including the judges of the District of New Jersey, ${ }^{169}$ who were rewarded for their support with three new judgeships. ${ }^{170}$ In addition to pointing to the deficiencies in the Act, soine judges also gently objected that the proposal was an intrusion on the independence of the federal judiciary. ${ }^{171}$ The

166. For example, the effectiveness of court-annexed ADR remains in substantial doubt. Lisa Bernstein, Understanding the Limits of Court-Connected ADR: A Critique of Federal Court-Annexed Arbitration Programs, 141 U. PA. L. REV. 2169 (1993); Dayton, supra note 64 , at 928.

167. See Shapiro, supra note 65 , at 1995 (using the example of judicially ordered early scheduling discussions with litigants).

168. William H. Erickson, Limited Discovery and the Use of Alternative Procedures for Dispute Resolution, 71 DENV. U. L. REV. 303 (1994).

169. H.R. Rep. No. 416, 101st Cong., 2d Sess. 5, at 79 (1990) (Letter of Chief Judge John F. Gerry).

170. Federal Judgeship Act of 1990, tit. II, 104 Stat. 5098, 5100 (1990).

171. See, e.g., The Civil Justice Reform Act of 1990 \& the Judicial Improvements Act of 1990: Hearings on S. 2027 \& S. 2648 Before the Senate Comm. on the Judiciary, 101st 
judges were supported in this contention, albeit without vigor, by the American Bar Association and the Department of Justice. When his bill met with so hittle approval from the knowledgeable persons most imvolved, Senator Biden redrafted his Act to strike the objectionable provisions mandating his system to assure early trial dates, and then secured its enactment. As enacted, CJRA in effect told the district judges to go back and work out local solutions to the problems that his draft bill had tried to address. The Act requires each district to appoint an advisory committee to study its docket and the causes of cost and delay, and to produce a plan to reduce those evils. The plans are authorized to include a menu of suggested case management techniques, ${ }^{172}$ virtually all of which were already im common usage in many districts, including measures to facilitate settlement. ${ }^{173}$ An advance guard of ten experimental districts was created. And the Act provided that the sun would set on the experiments with a report to Congress at the end of $1995,{ }^{174}$ suggesting the possibility that the sun will set on local plans as well.

Insofar as CJRA encourages experimentation, it is congruent with a long-held ambition of many judges and scholars to employ scientific methods to ascertam what works in procedure. ${ }^{175}$ Alas, there is very little science to be employed in these experiments. The experiments are uncontrolled; there is no scientific method employed in planning them; there are ninety-four experiments proceeding at once; and the experiments were to be completed

Cong., 2d Sess. 310, 333-44 (1990) [hereinafter Hearings on S. 2027] (statement of Hon. Robert F. Peckham made on behalf of the Judicial Conference of the United States).

172. 28 U.S.C. $\S 473($ a) (1994).

173. 28 U.S.C. $\$ 473(\mathrm{~b})$.

174. See $\$ \S 105(b)(3)$ and (c).

175. See, e.g., Paul D. Carrington, Foreword: The Scientific Study of Legal Institutions, LAW \& CONTEMP. PRoBs., Summer 1988, at 1; A. Leo Levin, Local Rules as Experiments: A Study in the Division of Power, 139 U. PA. L. REV. 1567, 1581-82, 1590-95 (1991); Laurens Walker, Perfecting Federal Civil Rules: A Proposal for Restricted Field Experiments, LAW \& CONTEMP. PROBS., Summer 1988, at 67; Laurens Walker, A Comprehensive Reform for Federal Civil Rulemaking, 61 GEO. WASH. L. REV. 455, 484-89 (1993). Louis Brandeis opposed enactment of the Rules Enabling Act and dissented from promulgation of the 1938 rules, apparently because he favored experimentation; but the experimentation he favored envisioned differences among the 50 states, with political accountability in each state. It is safe to assume that Brandeis would have opposed experimentation among 94 groups of federal judges who are accountable to no one. His views are discussed in Paul Freund, Mr. Justice Brandeis, in MR. JUSTICE 177, 189-92, (Allison Dunham \& Philip B. Kurland cds., 1964). 
within three years, long before secondary or tertiary effects can be experienced and measured. In this respect, the Act is further confirmation of the disjunction between the politics of court reform and the realities of what liappens in court. ${ }^{176}$

Not a word was uttered to explain the relation between the 1990 Act and the 1988 Act. Inasmuch as there was little new in the inenu of management techmiques each plan is authorized to include, it is possible that the 1990 Act was seen to create no significant conflict with the Federal Rules of Civil Procedure. Yet there was obvious tension between the encouragenent of local planning in 1990 and the suppression of local rulemaking im 1988. The clutter that Congress wanted to reduce in 1988 seemed to be the desired result in 1990. No effort was made to reconcile these conflicting signals.

The Act obliged each district court to consult with its "users," organized as the local advisory committee appointed to study its docket and recommend a plan. ${ }^{177}$ Such local advisory committees had been established as early as $1982 .{ }^{178}$ It was suggested that these consultations would make the local plans inore responsive to local problems and concerns, providing an element of democratic self-government in local rulemaking. ${ }^{179}$ But unlike a town or county or school district, a judicial district is a governmental unit without a political constituency. No one is commissioned to speak for the people of a judicial district because no one is in any way accountable directly or indirectly to the people whose lives are governed and whose rights are valued or devalued by the action or inaction of the local court. While rulemaking at the national level has with justification been described as undemocratic, ${ }^{180}$ local committees are no more delnocratic, and may well be less responsive to public concerns and to the public imterest, than are the committees of the Judicial Conference. ${ }^{181}$

176. See, e.g., Austin Sarat, The Litigation Explosion, Access to Justice and Court Reform: Examining the Critical Assumptions, 37 RUTGERS L. REV. 319 (1985) (criticizing court reformers' reaction to an alleged litigation explosion).

177. 28 U.S.C. $\S \S 472,478$ (1994).

178. Act of Apr. 2, 1982, 28 U.S.C. $\S 2077$ (b) (1994).

179. S. REP. No. 416, 101st Cong., 2d Sess. 15-16 (1990), reprinted in 1990 U.S.C.C.A.N. 6802, 6817-19; Jeffrey J. Peck, "Users United": The Civil Justice Reform Act of 1990, LAW \& CONTEMP. PROBS., Summer 1991, at 105, 109-10 (1991).

180. See WEINSTEIN, supra note 116 , at $6-8$; Hazard, supra note 52 , at $1286-87$ (reviewing WeINSTEIN, supra); Howard Lesnick, The Federal Rule-Making Process: A Time for Re-Examination, 61 A.B.A. J. 579, 579-80 (1975).

181. The Senate Committee Report quoted me as one favoring greater openness and 
My own experience with diverse committees composed of lawyers and judges is that the lawyers are conscientious, but tend to be co-opted by judges. That seems to have been the dynamic of most local advisory committees. However, when this does not happen, there is, as Lauren Robel ${ }^{182}$ and Linda Mullenix ${ }^{183}$ have observed, a greater hazard than co-optation. ${ }^{184}$ If advisory groups are dominated by lawyers who contmue to represent their chents, local plans will be the product of efforts to secure not civil justice but any available advantages over their chents' adversaries that can be secured by rule of court. Especially advantaged in such a process will be litigants and lawyers who appear repeatedly in a particular district and thus have sufficient stakes in shaping court rules to protect their imterests to make the effort worth their while. ${ }^{185}$ Indeed, if a truly representative group of litigants were to try to fashion a system of civil procedure for their own use, they would likely be unable to agree on any system and might conclude by calling for disinterested persons to fashion a system for them. One large advantage of the national rulemaking process created in 1934, seen as a disadvantage chiefly by those who expect to be disfavored by rules fashioned by disinterested persons, is that a committee of the Judicial Conference is virtually invulnerable to the influence of self-aggrandizing factional pohtics. Judicial committees are not without prejudices, but they are almost without interests, and that is an important qualification possessed by no local advisory committee.

One consequence of the creation of local committees to study dockets was to give added publicity to the shortfalls in productivity of soine district judges. The fear of public einbarrassment seems to

democracy in rulemaking. S. REP. No. 416, 101st Cong., 2d Sess. 13 (1990), reprinted in 1990 U.S.C.C.A.N. 6802, 6815-16. I did support the changes made for that purpose by the 1988 Act, but nothing I said in 1988 was fairly applicable to the form of participatory democracy embodied in the 1990 Act.

182. Lauren Robel, Grass Roots Procedure: Local Advisory Groups and the Civil Justice Reform Act of 1990, 59 BROOK. L. REV. 879, 902-03 (1993).

183. Counter-Reformation, supra note 12, at 406-07 (1992).

184. See also Edward D. Cavanagh, The Civil Justice Reform Act of 1990 and the 1993 Amendments to the Federal Rules of Civil Procedure: Can Systemic Ills Afflicting the Federal Courts Be Remedied by Local Rules?, 67 ST. JoHN's L. REV. 721, 734-55 (1993) (offering general criticism of local rulenaking).

185. See Marc Galanter, Why the "Haves" Come Out Ahead: Speculations on the Limits of Legal Change, 9 LAw \& SoC'Y REV. 95, 123-24 (1974). 
have prodded a few to do more judicial work. Early returns suggest that this may be the one positive effect of the Act. ${ }^{186}$

Making law for other people to obey is fun, and most lawyers suppose they can do it better than the next person. Unsurprisingly, therefore, some district courts leapt at CJRA's invitation to exercise a measure of legislative autonomy. ${ }^{187}$ None was more forthcoming than the Eastern District of Texas, and so its Plan raises the following six questions to be addressed in this Article:

(1) Does Congress have the constitutional power to authorize lower federal courts to disregard procedures mandated by the Supreme Court?

(2) If so, was that power exercised in 1990 in silent repudiation of the provisions of its unrepealed 1988 Act?

(3) Can Congress constitutionally delegate to Article III courts authority to enact fee-shifting laws?

(4) If so, did Congress grant them that authority in 1990 , or has it by its unrepealed Fees Act of 1853 forbidden such judicial legislation?

(5) Can the federal government constitutionally enact law imposing a fee-shifting offer of settlement rule on parties asserting claims or defenses arising under state law, solely on the basis of federal judicial jurisdiction over hitigation in which the claims or defenses are asserted?

(6) If so, has Congress effectively authorized federal district courts to decide whether such a rule should be imposed on such cases, or has it by the Rules of Decision Act of 1789 forbidden such federal intrusions on state law?

186. R. Lawrence Dessem, Judicial Reporting Under the Civil Justice Reform Act: Look Mom, No Cases!, 54 U. PTrT. L. REv. 687, 706-08 (1993); Charles G. Geyh, Adverse Publicity as a Means of Reducing Judicial Decision-Making Delay: Periodic Disclosure of Pending Motions, Bench Trials and Cases Under the Civil Justice Reform Act, 41 Clev. ST. L. Rev. 511, 532-36 (1993).

187. Accounts of local plans mclude: JUDICIAL CONFERENCE OF THE UNITED STATES, CIVIL JUSTICE REFORM ACT REPORT: DEVELOPMENT AND IMPLEMENTATION OF PLANS BY EARLY IMPLEMENTATION DISTRICTS AND PILOT COURTS (1992); Mary Brigid McManamon, Is the Recent Frenzy of Civil Justice Reform a Cure-All or a Placebo? An Examination of the Plans of Two Pilot Districts, 11 REV. LrTig. 329 (1992); Linda S. Mullenix, Civil Justice Reform Comes to the Southern District of Texas: Creating and Implementing $A$ Cost and Reduction Plan Under the Civil Justice Reform Act of 1990, 11 REV. LITIG. 165 (1992); Carl Tobias, Civil Justice Reform in the Fourth Circuit, 50 WASH. \& LEE L. REV. 89 (1993). 
If the answer to any one of these six questions is negative, the Eastern Texas Plan is invalid. I contend, albeit with uneven confidence, that the correct answers to all six are negative.

\section{LIMITS TO THE POWER OF CONGRESS OVER THE INTERNAL AFFAIRS OF THE FEDERAL COURTS}

The limits, if any, to the constitutional power of Congress over the conduct of federal courts have been mooted since the time of the first Judiciary Act. ${ }^{188}$ Acadennic and professional literature is replete with flat, imsupported statements of commentators-some declaring the absolute power of Congress over the judicial institutions it creates, others asserting broad limitations on legislative power. There is little need here for a full review of that literature. Senator Biden stands at one end of a spectrum of opinion; ${ }^{189}$ John Henry Wigmore at the other.

The applicable constitutional text is familiar and simple: "The judicial Power of the Umited States shall be vested in one supreme Court, and in such inferior Courts as the Congress may from time to time ordain and establish." And "[t]he Judges, both of the supreme and inferior Courts, shall hold their Offices during good Behaviour, and shall, at stated Times, receive for their services, a Compensation, which shall not be diminished during their Continuance in Office."191 This text thus suggests two limitations on the power of Congress that are applicable to CJRA. While Congress has no duty to provide for federal trial courts, and, according to convention, can limit federal jurisdiction as it chooses, ${ }^{192}$ and write laws that confine judicial discretion within a very narrow

188. Act of Sept. $24,1789,1$ Stat. 73.

189. S. REP. No. 416 , supra note 179 , at 8 , reprinted in 1990 U.S.C.C.A.N. at 6811. See also Peck, supra note 179, at 114.

190. U.S. CONST. art. III, \& 1.

191. Id.

192. See Ex parte McCardle, 74 U.S. (7 Wall.) 506, 514 (1869); Robert N. Clinton, $A$ Mandatory View of Federal Court Jurisdiction: Early Implementation of and Departures from the Constitutional Plan, 86 Colum. L. REv. 1515, 1593-1616 (1986); Henry M. Hart, Ir., The Power of Congress to Limit the Jurisdiction of Federal Courts: An Exercise in Dialectic, 66 HARV. L. REV. 1362, 1362-63 (1953). But McCardle was an exceptional case that may mean less than it appears. For careful analysis, see William W. Van Alstyne, $A$ Critical Guide to Ex Parte McCardle, 15 ARIz. L. Rev. 229 (1973); Proceedings of the Forty-Third Annual Judicial Conference of the District of Colunbia Circuit, 96 F.R.D. 245, 277-79 (May 9-12, 1982) (Remarks by Professor William W. Van Alstyne, Duke University School of Law). 
range, ${ }^{193}$ any courts the Congress creates must be inferior to the Supreme Court and must enjoy independence from control by the pohitical branches sufficient to their mission. The latter requires that they be free to perform the core judicial function of applying law to fact in those cases and controversies brought before thein without obstruction by the pohtically accountable branches of government. ${ }^{194}$

The utterances of the Supreine Court regarding the power of Congress over federal procedure have generally been tangential to a discussion of more immediate issues. The Court first addressed separation of powers with respect to civil procedure in 1812; it then upheld an exercise of the contempt power by a federal trial court, but construed the power narrowly and called on Congress to provide broader authority if it concluded that the courts it had created needed additional power. ${ }^{195}$ In 1873, the Court reaffirmed that the conteinpt power is "essential to the administration of justice" and implied that the power cannot be withdrawn by Congress. ${ }^{196}$ In a 1911 case arising out of a labor injunction, the Court described the conteinpt power as an "integral part of the independence of the judiciary." 197 In 1924, the Court upheld legislation providing for jury trials in conteinpt proceedings arising out of decrees enforcing the Clayton Act, ${ }^{198}$ but again affirmed that while Congress might regulate the contempt power, it could not withdraw that power because it is inherent in the constitutional duty to decide cases. In 1987, the Court explained Federal Rule of Criminal Procedure 42(b) as an expression of a federal court's inherent authority to appoint private counsel to prosecute conteinpt "without coinplete dependence on other Branches" of the government. ${ }^{199}$ These cases are not conclusive of the issue at hand.

193. See Mistretta v. United States, 488 U.S. 361, 412 (1989) (upholding act that limited judicial discretion regarding sentencing).

194. See Martin H. Redish, Federal Judicial Independence: Constitutional and Political Perspectives, 46 MERCER L. REV. 697, 701-23 (1995).

195. United States v. Hudson \& Goodwin, 11 U.S. (7 Cranch) 32, 34 (1812).

196. Ex parte Robinson, 86 U.S. (19 Wall.) 505, 510 (1873).

197. Goinpers v. Bucks Stove \& Range Co., 221 U.S. 418, 450 (1911).

198. Michaelson v. United States ex rel. Chicago, St. Paul, Minneapolis \& Onraha Ry., 266 U.S. 42, 71 (1924).

199. Young v. United States ex rel. Vuitton et Fils, S.A., 481 U.S. 787, 796 (1987). 
Similarly, the Court has spoken of the trial court's power to regulate the conduct of lawyers as one that is inherent and not dependent on any authority conferred on the courts by Congress. Its first utterance on this subject came in $1824 .{ }^{200}$ More recently, the Court has upheld the "inherent" powers of a district court to disiniss a case for failure to prosecute, ${ }^{201}$ to exclude a lawyer from practice before the court, ${ }^{202}$ and to impose sanctions on a party for litigating in bad faith. ${ }^{203}$ The relation between "inherent power" of the judiciary and powers that may not be withdrawn by Congress has never been illuminated by the Court for there has been no occasion to consider it. ${ }^{204}$ The most recent expression by the Court on the "inherent power" of federal courts, Chambers $v$. NasCo, ${ }^{205}$ insists on the prerogative of the courts, with or without legislative authorization, to punish parties who obstruct their proceedings or defile "the very teinple of justice." 206 These cases, like those bearing on the contempt power, are inconclusive.

Indeed, at the same time that the Court has asserted the inherent powers of the Article III judiciary, it has in dictuin repeatedly reaffirmed the power of Congress to enact legislation bearing on the conduct of the courts. Chief Justice Marshall did so as early as $1825 .{ }^{207}$ In interpreting the rules of court it has promulgated pursuant to the 1934 Rules Enabling Act, the Court has consistently referred for their source to its delegated power rather than to its inherent power. Senator Biden found it useful, in asserting his claim to absolute legislative power over the federal courts, to quote sentences from the Court's opinions in Sibbach $v$. Wilson $^{208}$ and Hanna v. Plumer. ${ }^{209}$ But the acknowledgments of

200. Ex parte Burr, 22 U.S. (9 Wheat.) 529, 530-31 (1824).

201. Link v. Wabash R.R., 370 U.S. 626,630 (1962).

202. In re Snyder, 472 U.S. 634, 643 (1985).

203. Chambers v. NASCO, Inc., 501 U.S. 32, 44 (1991).

204. But see Eash v. Riggins Trucking, 757 F.2d. 557, 562-63 (3d Cir. 1985) (en banc) (noting constitutional issues with respect to defining "inherent power"). The Third Circuit there distinguished three kinds of "inherent power," the first of which was beyond the reach of Congress to confine. Id. at 562. The Supreme Court noted the discussion, but did not ratify it in Chambers, 501 U.S. at 49 n.12.

205. 501 U.S. 32, 51-55 (1991).

206. Universal Oil Products Co. v. Root Ref. Co., 328 U.S. 575, 580 (1946).

207. Wayman v. Southard, 23 U.S. (10 Wheat.) 1, 43 (1825); see also Livingston v. Story, 34 U.S. (9 Pet.) 632, 655-56 (1835).

208. 312 U.S. 1,9 (1941).

209. 380 U.S. 460,473 (1965). Surprisingly to me, Professor Redish seems to endorse the Senator's misuse of these dicta. Redish, supra note 194, at 725. 
the authority of Congress are found in passages in which the Court is addressing considerations of federalisin, not those of separation of powers. In both cases cited by the Senator, the Court was affirming the power of the federal government to conduct its courts in a inanner agreeable to Congress rather than according to dictates of state legislatures. The two problems are easily conflated. We will return to the federahsin issue below because it is also innplicated by the Eastern Texas Plan.

Juxtaposed to the position of Senator Biden is that of Wigmore, perhaps the most distinguished American academic lawyer of the 20th century. Wigmore contended that procedural rulemaking is a judicial preserve Congress is powerless to imvade. ${ }^{210}$ Wigmore's position had been embraced in some state constitutional conventions inaking explicit the limitation on legislative power over courts, ${ }^{211}$ and would be adopted in other future conventions. ${ }^{212}$ Roscoe Pound challenged the breadth of the Wigmore argument as it apphed to federal courts, pointing out that the Supreme Court of the Umited States had acquiesced in legislative enactments that violated his principle. ${ }^{213}$ Pound, however, renewed the idea in support of the efforts of Chief Justice Arthur Vanderbilt to overhaul civil procedure in New Jersey. ${ }^{214}$

Pound's poimt about acquiescence is sound; the Supreme Court of the United States has indeed long acquiesced in legisla-

210. John H. Wigmore, All Legislative Rules for Judicial Procedure Are Void Constitutionally, 23 U. ILL. L. REV. 276 (1928).

211. E.g., WYO. CONST. art. V, § 2 (1890). For a recent application invalidating legislation regulating pleading in that state's courts, see White v. Fisher, 689 P.2d 102, 106-07 (Wyo. 1982).

212. E.g., N.J. CONST. art. VI, § 2, para. 3 (1948); see also A. Leo Levin \& Anthony G. Amsterdam, Legislative Control Over Judicial Rule-Making: A Problem in Constitutional Revision, 107 U. PA. L. REv. 1, 33 (1958) (noting that "[t]le Puerto Rico Constitution, the proposed Illinois Judicial Amendment, and perlaps the Alaskan Constitution grant to their respective highest courts a similar authority [to that of New Jersey]: power without review in the area of 'administration' "). Most state constitutions conferring exclusive rulemaking power on their highest courts also provide for soine form of election of judges. The political accountability of a court may bear on the suitability of locating broad rulennaking power in it.

213. Roscoe Pound, The Rule-Making Power of the Courts, 12 A.B.A. J. 599, 601 (1926); accord Charles W. Jomer \& Oscar J. Miller, Rules of Practice and Procedure: A Study of Judicial Rule Making, 55 M1CH. L. REv. 623, 642 (1957).

214. See Winberry v. Salisbury, 74 A.2d 406 (N.J. 1950) (Vanderbilt, C.J.); Benjamin Kaplan \& Warren J. Greene, The Legislature's Relation to Judicial Rule-Making: An Appraisal of Wiuberry v. Salisbury, 65 HARv. L. Rev. 234 (1951); Roscoe Pound, Procedure Under Rules of Court in New Jersey, 66 HARV. L. REv. 28, 28-29 (1952). 
tion regarding the management of the district courts. Moreover, the federal judiciary has often sought congressional action, generally welcoming the imprimatur of Congress to enhance the legitimacy of procedural arrangements potentially affecting substantive rights of citizens. But there has also been acquiescence by Congress, for it has seldom, if ever, presumed to enact legislation bearing on the routme of the federal courts; and on matters affecting the courts, Congress has seldoin proceeded without consulting the judges. Much of the legislation presently embodied in Title 28 is the product of a joint lawmaking venture in which representative federal judges had a significant hand. ${ }^{215}$ At times, the Department of Justice has played a role of monitoring cooperation between Congress and the courts. ${ }^{216}$ There has therefore never to this point been a serious conflict between the inherent power of independent courts and the power of Congress to regulate procedure im the courts it creates. Indeed, there is no instance in the history of federal legislation bearing on courts when Congress has interposed its power to diminish the authority of the Supreme Court over inferior federal courts.

One reason for traditional congressional acquiescence with respect to the internal affairs of the judiciary may be historical; English royal courts sitting in America generally fashioned their own procedure witlout legislative involvement, and hence, when the Constitution spoke of the "Judicial Power" in Article III, that power may well have been thought to include the power to fashion rules of procedure. ${ }^{217}$ But there are other practical reasons why Congress has not limited the contempt power or denied district courts power to regulate the conduct of lawyers, prescribed rules of pleading and practice, or limited the authority of the Supreme Court to direct the affairs of lower courts. One is that Congress has wanted, and continues to want, strong courts that can enforce the laws that it makes, and thus Congress has general-

215. Robert W. Kastenmeier \& Michael J. Remington, A Judicious Legislator's Lexicon to the Federal Judiciary, in JUDGES AND LEGISLATORS: TOWARD INSTITUTIONAL COMITY 54, 70-71 (Robert A. Katzmann ed., 1988).

216. PETer G. Fish, The Politics of Federal Judicial administration 91-165 (1973) (considering the role of the Department of Justice in the first balf of this century).

217. See Sara Sun Beale, Reconsidering Supervisory Power in Criminal Cases: Constitutional and Statutory Limits on the Authority of the Federal Courts, 84 COLUM. L. REv. 1433, 1466 n.217 (1984). 
ly lent its authority to the pursuit of that end, at least since the first term of the presidency of Thomas Jefferson. ${ }^{218}$ The dialogue between Congress and the Court on these matters can therefore be viewed as a pas de deux in which the Court's role is always to defer to Congress as the stronger partner, but also always to play the more creative and subtle role. Or it might be likened to the traditional family im which the husband, like Congress, is designated as the head of the household, but finds it imprudent ever to test the limits of any prerogatives that might be associated with that elevated status. In such relationships, an utterance or a gesture here or there cannot be taken as an important indication of what is really going on. Thus, the Court has never found it necessary to bring its utterances about the power of Congress over the federal courts together with its utterances about inherent judicial power.

There is constitutional artistry to this pas de deux. The institutions of Article III are blatantly undemocratic. That quality was built imto Article III and has simce been perceived to be essential to the role of courts in the government of our constitutional republic. Their relative freedom from factional pohtics is at once the source of their strength and of their limitations. The Constitution provides, the republic needs, and the people want the balancing dose of undenocratic ehisin that the federal courts bring to government. Because the independence of the federal judiciary is now generally accepted and approved by the American people, few factional pohiticians in Congress will dare assail it. Yet very few of us are ready to be governed by judges, especially those with lifetime appointments. A federal judiciary that overplays its hand is met with public indignation and defiance. Hence the dance of shared authority, and hence a happy imdeterminacy in our law: We do not know whether there is a fixed limit to the power of Congress over the federal courts, and we ought hope never to find out.

Other academic commentators have embraced Wigmore's position regarding the constitutional power of courts to make rules, ${ }^{219}$ while some have exphicitly rejected it. ${ }^{220}$ Mullenix is its

218. RICHARD E. Ellis, The JefFersonian CRISIS 233-50 (1971) (describing formation of the judiciary under the Jefferson administration).

219. See, e.g., Joiner \& Miller, supra note 213, at 628-30 (When the purpose of a rule is efficient judicial administration, "the scope of the inherent power vested in the courts 
most recent champion, and she would apply it to invahidate the Civil Justice Reform Act. ${ }^{221}$ To consider the Wigmore-Mullenix position, it is useful to imagme legislation that Congress has never enacted and is unlikely ever to enact. For exainple, suppose that Congress undertook to regulate the hours of holding court, amending Section 139 of Title 28 to provide that every district judge shall be on the bench from 8 a.m. to 5 p.m. five days a week, fifty weeks a year, national hohdays excluded. ${ }^{222}$ A coinparable measure would require executive officers of cabinet rank to keep such office hours. Congress creates departments of the executive branch and can abohsh them, just as it can abolish lower federal courts; however, having created thein, it cannot micromanage thein without taking leave of its constitutional role. Likewise, Congress cannot create pohtically servile institutions and call them courts of the United States. We can be sure that neither the judiciary nor the President's cabinet would ever punch Congress's clock if Congress were ever of a mind to establish one. To take other far-fetched examples, the Supreine Court ought not and would not subimit if Congress directed that the number of secretaries and law clerks assigned to individual judges shall vary according to a legislated formula linking support staff to the number of dispositions each judge achieves. Nor if it required the Chief Justice of the United States each year to assign the least productive (however defined) district judges to night court duties; perhaps Congress might permissibly confer such powers on the Chief Justice as the highest officer of the third branch, but it could not constitutionally require that the Chief exercise them. Of course, these examples are ludicrous, but the fact that they are so confirms that there is a core of

is complete and supreme.").

220. See, e.g., Michael M. Martin, Inherent Judicial Power: Flexibility Congress Did Not Write into the Federal Rules of Evidence, 57 TEX. L. REV. 167, 176-79 (1979) (finding that Wigmore's position is "no longer credible").

221. Linda S. Mullenix, Unconstitutional Rulemaking: The Civil Justice Reform Act and Separation of Powers, 77 MINN. L. REV. 1283, 1338 (1993) ("lf the Civil Justice Reform [Act] is not declared unconstitutional, there will be no end to the contimuing politicization of the judicial branch."). For a response to Mullenix, see Redish, supra note 194, at 725-30. Mullenix replied in Linda S. Mullenix, Judicial Power and the Rules Enabling Act, 46 MERCER L. Rev. 733 (1995).

222. Section 139 presently provides as follows: "The times for commencing regular sessions of the district court for transacting judicial bnsimess at the places fixed by this chapter shall be determined by the rules or orders of the court." 28 U.S.C. $\S 139$ (1994). 
control vested in the Supreme Court that is beyond the constitutional reach of Congress.

A likely aspect of that core is the Court's authority over inferior courts. Congress has never attempted to diminish that authority and is not likely to do so. But if Congress did so forget itself, it is unlikely that the Court would submit, nor should it. Congress could not authorize each district court to become a law unto itself with respect to matters that are procedural.

Congress has acknowledged the special standing of the Supreme Court as an institution having responsibilities not wholly subject to legislative domimion. That acknowledgment was expressed in the supersession clause included in the provisions of the 1934 Act, which gives overriding effect to procedural rules that clash with pre-existing acts of Congress. ${ }^{223}$ Pursuant to that provision, a valid rule of procedure promulgated by the Supreme Court can override a prior statute, just as a valid statute can override a prior rule of court. An example of its operation is provided by the relation between Rule 54 of the 1938 rules and the Fees Act now codified as Section 1920 of the Judicial Code. ${ }^{224}$ The Fees Act as it stood before 1938 provided that the costs histed in the Act "shall" be taxed, leaving the district court no discretion in the matter. In 1938, Rule 54(d) conferred discretionary power on the court to withhold the taxation of costs, presumably to create an additional incentive to the parties and counsel to conduct theinselves in a suitable inanner. The rule, if valid, superseded the statute. Whether it did or not, the change was unobjectionable to Congress, for in 1948, it amended section 1920 to conform to the rule by substituting "may" for "shall" in section $1920{ }^{225}$

Such a supersession clause is contained in no otler federal law authorizing an agency or board to exercise lawmaking responsibility. ${ }^{226}$ It is an act of Congress disavowing sole power over procedure in federal courts. The one other use made of supersession was in legislation enacted in the 1950s authorizing the executive branch of the federal government to reorganize itself to effect economies in administration. ${ }^{227}$ The supersession clause in the

223. 28 U.S.C. § 2072 (1994).

224. 28 U.S.C. § 1920 (1994).

225. Act of June 25, 1948, 62 Stat. 869, 955.

226. But cf. INS v. Chadha, 462 U.S. 919 (1987) (holding unconstitutional a provision for a one-house Congressional veto of administrative action).

227. See Act for the Establishment of a Commission on Organization of the Executive 
Rules Enabling Act was carefully reconsidered in 1988 and retained; it was thought to serve the national interest because it empowered the Court through its rulemaking subordinates to harmonize national rules. It also enables the Court to retain a ineasure of control useful in maintaining the integrity of the process employed by the lower federal courts. Its presence in the 1988 Act reflects the judgment of Congress that the Supreme Court is no ordimary delegate, but has a constitutional responsibility for procedure in district courts. ${ }^{228}$

This is not to say that the Rules Enabling Act is constitutionally required. Congress created the Judicial Conference of the Umited States and could abolish it. It created the rulemakmg process and could abolish that. ${ }^{229}$ Certainly it could repeal the supersession clause. But it cannot exclude the Supreme Court from the authority and responsibility for giving direction to lower courts that ann to ensure the fidelity of those lower courts to the central judicial task of applying law to facts. If Congress abolisled the rulemaking infrastructure, the Court would face three choices. One option would be to fashion a federal procedure by means of caselaw erected on the Constitution and whatever suitable statutory base Congress might have provided. To some extent, such caselaw has materialized within the loose framework of the 1938 Rules. ${ }^{230}$ Such a resort to caselaw would result in a measure of costly havoc, and in the short term would raise an issue whether due process of law requires that there be some rules of the game announced in advance of the coininenceinent of play. ${ }^{231} \mathrm{~A}$ second option would be to legislate a federal procedure without the help of the Judicial Conference or any other subordinate body approved by Congress. The Court is poorly organized to perform this function without help, but it is an nnagmable response. The third

Branch of Government, Pub. L. No. 108-83, ch. 184, 67 Stat. 142 (1953). On the supersession clause in this legislation, see RONALD C. MOE, THE HOOVER COMMISSIONS REVISITED 84-90 (1982); BRADLEY D. NASH \& CORNELIUS LYNDE, A HOOK IN LEVIATHAN 17-20 (1950).

228. See Paul D. Carrington, "Substance" and "Procedure" in the Rules Enabling Act, 1989 DUKE. L.J. 281, 322-26; see also Tyrrell Williams, The Source of Authority for Rules of Court Affecting Procedure, 22 WASH. U. L.Q. 459, 474 (1937).

229. This point is generally assumed. E.g., WINIFRED R. BROWN, FEDERAL RULEMAKING: PROBLEMS AND Possibilities 39 (1980).

230. E.g., Celotex Corp. v. Catrett, 477 U.S. 317 (1986); Hickman v. Taylor, 329 U.S. 495 (1947).

231. Eash v. Riggins Trucking Inc., 757 F.2d 557, 568-71 (3d Cir. 1985) (en banc). 
option, seemingly the most practical, would be to revert to the policy of the Conformity Act and direct federal district courts to adhere to local state practice "as near as nnay be." Balkanizing this would be, but fifty states are fewer than ninety-four districts, and the states have a political legitimacy that the district courts can never attain.

I thus conclude that Congress lacks constitutional authority to disable the Supreme Court froin performing its constitutional responsibilities for the direction of "inferior" courts to ensure their fidelity to law. If CJRA attempted to do that, it is unconstitutional and the Court would be fully justified in asserting the superior authority conferred upon it by Article III.

\section{CJRA AS AN EXERCISE OF CONGRESSIONAL AUTHORITY OVER THE RELATIONSHIP BETWEEN THE SUPREME COURT AND "INFERIOR COURTS"}

Professor Mullenix's contention that the Civil Justice Reform Act is invalid rests on her broad reading of the Act as an einpowerment of district courts to do anything that strikes thein as likely to reduce cost or delay. She supposes that the Act purports to disable the Supreme Court from performing its constitutional duty to keep the district courts in line-to assure that we have one legal system, not ninety-four. But Dean Robel contends that there is no sufficient reason to read the CJRA as conferring so broad an authority on district courts that these issues must be raised. ${ }^{232}$

There have been other diverse readings of the 1990 Act. Edward Wesley was anong the first to speak to the issue of the autlority the Act conferred on "inferior courts"; he thought it authorized local departures from the national rules but only on the narrow range of matters explicitly suggested in the Act. ${ }^{233}$ Justice Scalia, dissenting from the promulgation in 1993 of the new Rule 26, assumed that the Act authorized expermiental deviation froin the Federal Rules, at least with respect to the regulation of discovery; his position may be that of Wesley. ${ }^{234}$ Judge William

232. Robel, supra note 87.

233. His views are publisled. Edwin J. Wesley, The Civil Justice Reform Act; the Rules Enabling Act; the Amended Rules of Civil Procedure; CJRA Plans; Rule 83-What Trumps What?, in REvoluTIONARY CHANGES IN PRACTICE UNDER THE NEW FEDERAL RULes OF CrVIL PROCEduRE 456 (Hon. Marvin E. Aspen \& Jerold S. Solovy eds., 1994).

234. See Amendments to Federal Rules of Civil Procedure, 146 F.R.D. 401, 512 (1993) 
Schwarzer, the Director of the Federal Judicial Center, apparently made the Mullenix assumption; without attending to the problems of statutory and constitutional interpretation, he suggested experiments with fee-shifting offer-of-settlement rules. ${ }^{235}$

The Civil Rules Advisory Committee recommended the 1993 revisions of the discovery rules on the assumption that Robel's reading is probably correct. It gave sustained attention to the issue of potential conflict between the Rules and local plans. Prior to 1988 , there had been many local rules limiting the number of interrogatories, and some local rules limiting the number or length of depositions. Whether or not these were "not imconsistent" with the discovery rules before 1988, they were almost surely invalid after the amendment of the Rules Enabling Act limiting local rulemaking, and the Committee was therefore compelled to consider whether limitations on discovery should be mcluded in the national Rules. In 1989, it was considering and proposing rules amendments designed to bring the national rules into lime with useful local rules that may have been rendered invahid by the 1988 Act. It was then noticed that some districts were requiring an early meeting of counsel to exchange disclosures of obviously discoverable material as a predicate to a meeting with the court to fix limits on the amount of discovery suited to their particular case. After the Committee published for public comment a draft incorporating this idea, it became apparent that its draft was beimg mcluded in many local plans promulgated under CJRA. This becaine a matter of immediate concern to the Committee when it concluded that its draft was not in satisfactory form to be adopted as a national rule. Although not yet fully convinced that disclosures and standard limits on discovery are a good idea, and disimclimed to favor local options with respect to such matters, the Committee concluded that it was the better part of valor to accommodate the local planning process by authorizing such "experimental" departures from the national rules. Its purpose was thus to facilitate some of the local planning being done pursuant to CJRA. Numerous persons who opposed the disclosure requirements did so on the ground that the Committee should not impede local experiments with similar provisions contamed im plans

(Scalia, J., dissenting).

235. See William W. Scliwarzer, Fee-Shifting Offers of Judgment-An Approach to Reducing the Cost of Litigation, 76 JUDICATURE 147 (1992). 
promulgated under CJRA and should await the outcome of those experiments. Persons making this argument at the Committee's hearings were asked to poimt to text in CJRA supporting their assumption that such provisions in local plans were vahd; none did so. The same persons were also asked to reconcile their assumption regarding CJRA with the 1988 legislation that the Committee was also obliged to recognize and enforce. None ventured to do that, either. Accordingly, the Civil Rules Committee, comprised largely of federal judges, acted on the belief that unless it authorized such experiments by amending Rule 26 , some and perhaps many of the provisions set forth in proposed local plans to regulate discovery would be imvalid. ${ }^{236}$ The same view was accepted without challenge im the Standing Committee on Rules of the Judicial Conference of the United States, which reviewed the proposal with care, and passed it along to the Judicial Conference and the Supreme Court for action. Clearly, the rulemakers are not the appropriate authority to have the last word in a conflict between their rules and local plans, but it is pertiment that numerous federal judges, most of them district judges, supposed that a local plan promulgated under CJRA was not authorized to override a national rule, much less other provisions of unrepealed legislation.

Robel and the Committee were correct. Bold statements in the legislative history about the absolute power of Congress to regulate the courts it creates ${ }^{237}$ are scarcely a sufficient basis to loold that the Congress in 1990 actually exercised any power it might or might not possess to authorize district courts to defy not only the Supreine Court but also Congress's own utterances of 1988. The 1990 Act should be read, as Robel and the Committee read it, agamst the background of unrepealed provisions of the Judicial Code and, if possible, to avoid constitutional issues. ${ }^{238}$

In examining the text of CJRA in search of an explicit provision authorizing local defiance, one finds instead provisions requiring that local plans be subject to the scrutimy of higher authority

236. Paul D. Carrington, Learning from the Rule 26 Brouhaha: Our Courts Need Real Friends, 156 F.R.D. 295, 304-06 (1994); cf. Rochelle C. Dreyfuss, The What and Why of the New Discovery Rules, 46 FlA. L. REV. 9, 20-21 (1994) (identifying problems of "nationwide uniformity" and "case uniformity").

237. E.g., Hearings on S. 2027, supra note 171 (statement of Sen. Joseph R. Biden, Jr.).

238. The authoritative treatment is still the concurring opinion of Justice Brandeis im Ashwander v. Tennessee Valley Authority, 297 U.S. 288, 346-56 (1936). 
in the chief judges of the circuits and in the Judicial Conference of the Uinited States. ${ }^{239}$ The implication of these provisions is that the local plans should be consistent with the patterns of practice in otlier districts. Carl Tobias has deinonstrated that the review systein conteinplated by the Act is, regrettably, almost inoperative. ${ }^{240}$ Since his writing, the Judicial Conference has questioned a circuit rule adopted by a U.S. Court of Appeals and induced that court willingly to inodify its rule to bring it into line with the Rules Enabling Act. ${ }^{241}$ Nevertlieless, the Judicial Conference and the chief judges lack the resources in attention and energy to perform their role as reviewers of all local plans as envisioned by CJRA. Their failure to perform this function more aggressively, however, cannot be taken as an indication that it need not be performed even by a reviewing court confronted with a provision in a local plan that is at odds witlr the national law.

It is also significant that unlike the Rules Enabling Act enacted in 1988, CJRA contains no supersession clause. Local plans, unlike newly promulgated national rules, are therefore required without exception to conform to all legislation enacted by Congress. Moreover, it seems clear that the 1993 amendments to the discovery rules, while they supersede no explicit provision of CJRA, must surely supersede any local plans in conflict with those anended rules. Thus, any plan tliat included disclosure requirements inore onerous than those authorized by new Rule 26(a)(1) seeins to have been pro tanto superseded. ${ }^{242}$ In addition, the recent amendment to Rule 83, inade to conform that rule to the 1988 Act, inust supersede any implication in CJRA that local plans may be inconsistent with the national rules.

239. 28 U.S.C. \& 474 (1994).

240. The Judicial Conference is a biennial meeting of judges, each of whom is overloaded with judicial work and who confronts at the meeting an agenda of staggering length, many of the items being appalling in their insignificance. Its meetings are accordingly dominated by work of the staff of the Administrative Conference of the United States. See Carl Tobias, Suggestions for Circuit Court Review of Local Procedures, 52 WASH. \& LEE L. REv. 359, 363-67 (1995).

241. See Memorandum from Daniel R. Coquillette to Committee on Rules of Practice and Procedure (Nov. 30, 1994) (on file with author).

242. Reasonable minds may differ on this point. Some districts, notably the Northern District of California, require additional disclosures. The text of Fed. R. Civ. P. 26(a)(1) provides for disclosures "except to the extent directed by local rule." I read that to mean that local rules can require disclosures to the extent provided in Rule 26(a), but not more. 
If read to require continued obedience to existing national law, CJRA is consistent with the action taken by Congress in 1988 when it commanded the federal courts to diminish the localisin creeping into the procedural system. If not so read, then Congress speaks with a forked tongue and has almost simultaneously commanded that there shall be uniformity and diversity among the districts.

Does the restrained interpretation of CJRA adopted by Robel and the Civil Rules Committee leave the Act an empty vessel? Hardly. There remains a substantial statutory program coinpatible with the Federal Rules and the Rules Enabling Act. District courts are authorized and expected to experiment with docket administration, case management, alternative dispute resolution, and the uses of magistrate judges. All of these are quite consistent with Federal Rule 16, as are novel systems of regulating lawyer misconduct, such as the peer review system estabhshed in the Montana district court to punish discovery abuse. ${ }^{243}$ None of these devices are likely to make a material difference in the cost of civil hitigation in most cases or in the law's delay, but any of them may make a marginal difference, albeit perhaps at the cost of other values of civil justice not addressed by CJRA. None of the measures so authorized are demonstrably inferior as cost or time savers to the devices included in the Eastern Texas Plan.

When and if Congress ever exphicitly authorizes a district court to depart froin mandates of the Supreme Court, it will be time to decide whether Congress has that power to subvert the hierarchy of the federal judiciary. Meanwhile, I conclude that CJRA did no such mischief: It did not authorize local plans in defiance of national rules.

\section{THE Non-Delegability of ARTicle I} LEGISLATIVE POWER TO ARTICLE III JUDGES

A second line of objection to the fee-shifting offer of settleinent rule and the regulation of contingent fee contracts contaimed in the Eastern Texas Plan is that such matters are not within the narrow range suited to governance by a rule of court enacted by an Article III court.

243. Carl Tobias, The Montana Federal Civil Justice Plan, 53 MONT. L. Rev. 91, 95-97 (1992). 
Martin Redish has brashly argued that all federal laws, whether substantive or procedural, must be enacted by Congress and only by Congress. ${ }^{24} \mathrm{He}$ contends that Article III courts may not constitutionally make rules because ruleinaking is a "striking departure" from the process of deciding cases, which is the only activity federal courts are commissioned by Article III to perform. ${ }^{245} \mathrm{His}$ is a powerful if overstated point, often lost to view by noderns obsessed with the lawmaking effect of opimions of the court. ${ }^{246}$ Although opinion-writing partakes of lawinaking, it is an art confined by the particular dispute an opinion purports to decide. Drafting legislation is more nearly a freehand art. To decide an existing dispute framed by contending parties is an activity for which the independence of the judiciary is a very useful qualification; inoreover, the public necessity of the decision affords moral legitimacy to the act. On the other hand, to prescribe standards of conduct by which future disputes will be judged is an activity for which the independence of the judiciary from politics is a disqualification wherever a republican form of government abides. ${ }^{247}$ For these reasons and perhaps others, the distinction between Article I and Article III institutions lias substance requiring that it be observed.

The distinction is, as must be acknowledged, sometinies muddy. A source of muddiness has been the evolution of the concept of federal common law. The Court has on occasion ventured to decide cases on substantive primciples having no visible basis in the

244. Martin H. Redish, Federal JuRisdiction: Tensions in the allocation of JUDICIAL POWER 21 (2d ed. 1990).

245. Id. "The judicial Power shall extend to all Cases, in Law and Equity . . . ." U.S. CONST. art. III, \& 2.

246. E.g., Louise Weinberg, Federal Common Law, 83 Nw. U. L. Rev. 805, 813, 835 (1989) (arguing that the difference between Article I and Article III powers is not significant) [hereinafter Federal Common Law]. She finds these powers to be "coordinate." Id. at 813. See also Martin Redish, Federal Common Law and American Political Theory: A Response to Professor Weinberg, 83 Nw. U. L. REv. 853 (1989); Louise Weinberg, The Curious Notion That the Rules of Decision Act Blocks Supreme Federal Common Law, 83 Nw. U. L. REv. 860 (1989).

247. The obligation to respect the institutions of self-government is not accepted by Weinberg. Federal Common Law, supra note 246, at 845-46. She argues that congressional gridlock justifies the federal courts in taking matters into their own hands and making any law they deem needed. Id. She is, of course, correct that Congress is often gridlocked. Congress was designed by James Madison and his associates to gridlock, and the electorate generally votes to ensure its continuance. See generally WILLIAM N. ESKRIDGE, DYNAMIC STATUTORY INTERPRETATION 113, 156 (1994). 
text of legislation. ${ }^{248}$ But in doing so, it has remained within the framework of cases that the federal courts were obligated to decide. There is no hint in the Court's opinions suggesting that it could codify federal common law, however desirable such a codification inight be.

The constitutional restraint on rulenaking by courts coinplements the previously discussed constitutional restraint on congressional intrusion into the internal affairs of the judiciary. While Congress cannot displace the Supreme Court in the judicial hierarchy, neither can the federal courts displace Congress by legislating, except with respect to inatters intrinsic to their own routines. ${ }^{249}$

It is not necessary to rely on these inferences from the constitutional text distinguishing Article I and Article III institutions because the constitutional principle is also expressed in legislation. That expression is found in the provisions of the Rules Enabling Act explicitly forbidding the promulgation of rules modifying or abridging substantive rights. Possibly that restrictive language is redundant, ${ }^{250}$ appearing as it does as part of a provision authorizing rulemaking only with respect to inatters of practice and procedure. But if redundant, it nevertlieless stands as a confirmation by Congress that the Court cannot enact a code governing the full range of inatters on which the federal governinent may legislate, or even on the full range of matters that inight arguably be classified as procedural for soine other purposes. Whether the statute expresses precisely the same limitation on the Court's rulemaking authority as that arising by implication from the text of the Constitution is an issue that has not arisen, and is of no present importance. It is sufficient here to acknowledge that the statutory proscription against substantive rules of court has constitutional roots.

248. E.g., Boyle v. United Technologies Corp., 487 U.S. 500 (1988).

249. See also Ralph U. Whitten, Separation of Powers Restrictions on Judicial Rulemaking: A Case Study of Federal Rule 4, 40 ME. L. REv. 41, $48-54$ (1988). In response to concerns voiced by Professor Whitten, the Civil Rules Committee flagged one provision of its 1991 revision of Rule 4, calling the attention of Congress to the fact that the power of the Court to promulgate such a rule was subject to question. See Proposed Amendments to the Federal Rules of Civil Procedure, 110 S. Ct., Advance Sheet 1 at lxxxviii (1989).

250. The sentence of 28 U.S.C. $\$ 2072$ forbidding the nodification or abridgment of substantive rights was regarded in 1934 as mere surplusage. Burbank, supra note 39 , at 1121-31. 
The term "substance" as it appears in the Rules Enabling Act is a famously elastic term. It has different meanings in different contexts depending on the purpose for which the substance-procedure distinction is made; I have demonstrated elsewhere four different meanings of the term merely in its applications to the Rules Enabling Act and the Rules of Decision Act as interpreted im Erie. $^{251}$ In the present context, "substantive" seems to refer to matters extrinsic to the work of Article III courts applying law to facts. Conduct outside the courthouse having hitle or no bearing on the functioning of the courts is not subject to governance by rule of court. Laws governing such conduct must be made by those who are politically accountable as Article III courts never can be.

Precisely which matters are to be deemed substantive and which matters are to be deemed procedural for the purpose of judging the validity of a rule of court is a question largely remaining open. ${ }^{252}$ Perhaps the most enlarged view of the umverse of procedure is presented by those persons, all of thein academics, who advocate "non-trans-substantive" rules of court. ${ }^{253}$ Their idea, redolent of the common law forms of action, is that different sets of rules might and ought be devised for different classes of cases-that classifications be made according to the substance of the disputes. ${ }^{254}$ Leaving aside the merits of this suggestion, ${ }^{255}$ the question arises whether politically independent Article III courts constitutionally can consider enacting such a procedural code.

251. Carrington, supra note 228.

252. See 2 WRIGHT \& MILLER, supra note 79, § 4509 (1990).

253. Robert M. Cover, For James Wm. Moore: Some Reflections on a Reading of the Rules, 84 YALE L.J. 718, 718 (1975), seems to have been the first proponent of this idea. More recent expressions are Stempel, supra note 12, at 70-71; Subrin, supra note 70, at 2001; Judith Resnik, The Domain of Courts, 137 U. PA. L. REV. 2219, 2220 (1989); Carl Tobias, The Transformation of Trans-substantivity, 49 WASH. \& LEE L. REV. 1501, 1508 (1992).

254. This idea is to be distinguished from proposals that there be different rules for cases involving smaller stakes; although sometimes referred to as uon-trans-substantive, such rules, which are familiar in the practice of most state courts, do not distinguish cases according to the substantive nature of the disputes. See, e.g., Mark C. Weber, The Federal Civil Rules Amendments of 1993 and Complex Litigation: A Comment on Transsubstantivity and Special Rules for Large and Small Federal Cases, 14 REV. OF LITIG. 113 (1994).

255. See Vices, supra note 63; Making Rules, supra note 55; Shapiro, supra note 65, at 1997; Marcus, supra note 56. 
An enlarged interpretation of the Court's authority to legislate on all matters affecting the judiciary gains some support froin the fact that for much of the last two centuries, Congress has had httle time or attention to devote even to important matters of judicial administration. Expansive interpretations of the power of the Court to legislate may also reflect the dissatisfaction with Congress that has caused the despair of many who interpret other powers of the judiciary expansively. ${ }^{256}$ There is a tendency of some, perhaps academic observers in particular, to suppose that if Congress will not or camiot solve a problem, then it inust be the prerogative of courts to do so. This view sometimes assumes a wisdoin of courts that they may not possess, and disregards the constitutional reahties that the incapacities of Congress are imposed by constitutional design and generally reflect the indecision of the people, and that the courts' imdependence unfits them for the tasks assigned to Congress by Article I.

Like the corresponding limit on the power of Congress, the limit on the power of the Court to enact substantive judicial legislation remains largely untested. Congress has never tried explicitly to confer power on the Supreme Court to enact substantive legislation, and the Court has not made it a practice to enact plainly substantive laws as rules of court. ${ }^{257}$. For the most part, federal civil rulemakers have observed the mjunction uttered by Charles Alan Wright in 1967 forbidding changes in procedure that deliberately "affect substantive rights." confining limit on what the Court can be authorized to do, it is therefore again necessary to parade imagimary examples.

One example is suggested above. It seems clear the federal courts could not constitutionally enact a code re-establishing forms of action distinguishing different classes of claims according to the different substantive riglits invoked by claimants. To do so would necessarily resnlt in favoring some identifiable substantive claims or defenses and disfavoring others. The choice as to whose rights

256. See, e.g., Akhil R. Amar, Philadelphia Revisited: Amending the Constitution Outside Article V, 55 U. CHI. L. REV. 1043, 1076-87 (1986); Larry Kramer, The Lawmaking Power of the Federal Courts, 12 PACE L. REv. 263, 271-72 (1992).

257. See John Hart Ely, The Irrepressible Myth of Erie, 87 HARv. L. REv. 693, 718-20 (1974) (suggesting that the Court should examine rules more cautiously in this respect).

258. Charles A. Wright, Procedural Reform: Its Limitations and Its Future, 1 GA. L. REV. 563, 568-69 (1967). 
should be preferred and given special procedural treatment is one that a politically unaccountable and invulnerable institution has no business making. To be sure, in deciding cases, Article III courts every day inake distinctions in the application of their generalized rules of court, and some of these correspond to differences in the substance of the cases they are deciding. But there is a difference of constitutional import between making such distinctions in response to the exigencies of deciding cases and making general, prospective rules that declare soine people's rights to be inore important than other people's rights. Congress is therefore the only forum to consider whether substance-specific rules of court are needed..$^{259}$ Thus, Rule 2 of the Federal Rules of Civil Procedure $^{260}$ serves a constitutional purpose.

Other imaginary examples inerit consideration. Congress has not authorized the Supreine Court to enact a general statute of limitations setting time limits for the commencement of the full range of federally created rights, ${ }^{261}$ and it perhaps could not do so without inviting the Court to exceed the limits of activity suited to an Article III institution. Nor does it seem that Congress could authorize the Court to adopt or not, as federal rules of court, every section of the Restatement, Second, of Judgments. ${ }^{262}$ Or to enact rules regulating the seizure and sale of assets in the course of execution of federal judgments ${ }^{263}$ to include sucli inatters as hoinestead exemptions and restrictions on wage assignments. ${ }^{264}$

259. Cf. Mary Kay Kane, The Golden Wedding Year: Erie Railroad Company v. Tompkins and the Federal Rules, 63 NOTRE DAME L. REV. 671, 691 (1988). Kane points to the Truth in Leuding Act as an example of a successful petition to Congress on such a matter; the Act was annended in 1982 to limit the impact of Rule 23. Id. at $691 \mathrm{n} .142$; see 15 U.S.C. $\$ 1640($ a)(2)(B) (1994).

260. FED. R. CIV. P. 2: "There shall be one form of action to be known as 'civil action." "

261. See Richard L. Marcus, Fraudulent Concealment in Federal Court: Toward a More Disparate Standard?, 71 GEO. L.J. 829, 850-51 (1983). In 1990, Congress took a first step in dealing with the chaos of federal limitatious law. Act of Dec. 1, 1990, Pub. L. No. 101-650, 104 Stat. 5114 (codified as annended 28 U.S.C. § 1658 (1994)).

262. RESTATEMENT (SECOND) OF JUDGMENTS (1982).

263. In 1988, a section of the American Bar Association proposed just such a rule of court; the Civil Rules Committee refused to consider it. One reason was the view held by at least some members that such a rule would be substantive and should be enacted by Congress.

264. FED. R. CIV. P. 64 conforms provisional remedies in federal court to state law. FED. R. CIV. P. 69(a) conforms the procedure on execution to state law. For reasons stated in this article, the Court is powerless to promulgate federal legislation on these matters. 
Or to make laws applicable to all federal cases setting the fees paid to attorneys or to expert witnesses by all parties. All these subjects are for some purposes regarded as "procedural." 265 But they also pertain to matters directly affecting the value of substantive rights and are only incidentally connected to relations between courts and lawyers or to conduct in court-the matters that are the appropriate subjects of court rulemaking. ${ }^{266}$

This is not to say that any Federal Rule touching on the illustrative topics is invalid. There are several rules having marginal bearing on the statute of limitations; Rule 15(c), which provides for the relation back of amendments, is an example. Other rules bear on the preclusive effect of judginents; Rule 13(a), which requires defendants to assert certain counterclaims is an example; perhaps that Rule could go further and require joinder of related claims by plaintiffs, as a Michigan state court rule does, ${ }^{267}$ but surely the Court cannot by rule of court prescribe general principles of issue preclusion. The court may regulate attorneys' fees paid by a class in Rule 23 litigation as an incident to its power to approve class action settlements. But Rules 13, 15, and 23 are legitimate rules of pleading that are integral to a court's process; the external consequences of these rules are incidental to the solution of problems encountered im administering a process designed to apply law to facts. ${ }^{268}$ It was for this reason that Rule 19 withstood attack as a violation of the Rules Enabling Act; its exterual consequences were merely incidents to a legitimate effort of the rulemakers to provide guidance to federal courts when parties present for decision only one part of a larger controversy. ${ }^{269}$ Similarly, Rule 35, which authorizes compulsory physical and mental examinations, withstood attack despite its manifestly extrinsic bearing on the personal mjury plamtiff's privacy because the invasion of privacy effected by the rule was incidental to the

265. See Walter Wheeler Cook, "Substance" and "Procedure" in the Conflict of Laws, 42 YALE L.J. 333, 336 (1933).

266. See Wright, supra note 258 , at 568-71.

267. MiCH. R. CT.-ST. 2.203(A)(1).

268. Rule 23 as amended in 1966 may also overstep the authority of the Court. See Jonathan M. Landers, Of Legalized Blackmail and Legalized Theft: Consumer Class Actions and the Substance-Procedure Dilemma, 47 S. CAL. L. REV. 842, 849-61 (1974).

269. Provident Tradesmens Bank \& Trust Co. v. Patterson, 390 U.S. 102 (1968). Cf. Boggs v. Blue Diamond Coal Co., 497 F. Supp. 1105, 1108-21 (E.D. Ky. 1980) (holding that Rule 25(a) is "procedural" under the Rules Enabling Act). 
entirely legitimate purpose of discerning the truth with respect to controverted issues of fact. ${ }^{270}$ And Rule 11 was upheld in its apphication of sanctions on lawyers and unrepresented parties for their inappropriate utterances in court. But there are limits to the reach of these rules; it is at best doubtful that a rule of court could inandate the imposition of sanctions on represented parties for their negligence in pursuing unjust claims or asserting unfounded defenses. ${ }^{271}$ If Rule 19 were recast, as soine might wish, to create a duty of nonparties to intervene in lawsuits possibly affecting their interests, ${ }^{272}$ or to define a concept of "virtual representation," 273 the rule would seein clearly beyond the pale of legitiinate court ruleinaking. ${ }^{274}$

Another example useful in the context of CJRA was offered by Maurice Rosenberg; he distinguished court-systein delay resulting from inaction by the court from lawyer-cansed delay ${ }^{275}$ resulting froin the mutual unreadiness of adversaries for the next step in the process of adjudication. The former is a procedural problein internal to the courts and is appropriately addressed by judicial rulennakers; the latter is arguably too extrinsic to the administration of due process and is therefore not a problem to be regulated by legislation enacted by an independent judiciary.

That a fee-shifting law is "substantive" for the purposes of the present distinction seems reasonably clear. The Supreme Court lias held that it lacks authority to create fee-shifting rights even on a case-by-case basis in the exercise of its equity powers. ${ }^{276} \mathrm{~A}$ fortiori, it cannot legislate such laws by rule of court. This would seem equally true with respect to legislation bearing on contingent fee arrangeinents. If Congress desires fee-shifting offer of settlement rules and limitations on contingent fees, it must itself take pohtical

270. Sibbach v. Wilson \& Co., 312 U.S. 1, 13-14 (1941).

271. See Business Guides, Inc. v. Chromatic Communications Enter., Inc., 498 U.S. 533, 564-69 (1991) (Keunedy, J., dissenting).

272. 2 WRIGHT \& MILLER, supra note $79, \S 4452$ (reviewing cases that suggest such a possible duty).

273. Id. at $\S 4457$ (describing the "virtual representation" theory in which a nonparty is precluded if a party with adequately similar interests has tried the case).

274. Cf. Cold Metal Process Co. v. United Eng'g \& Foundry Co., 351 U.S. 445, 451-53 (1956) (holding amended Rule 54(b) within court rulemaking power).

275. Maurice Rosenberg, Court Congestion: Status, Causes and Proposed Remedies, in The Courts, The PUBlic and The LAW Explosion 29, 32-37 (Harry W. Jones ed., 1965).

276. Alyeska Pipeline Serv. Co. v. Wilderness Soc'y, 421 U.S. 240, 247-71 (1975). 
responsibility for such enactments. Such a proposal is now pending in Congress. ${ }^{277}$

I conclude that Congress cannot delegate to any Article III court the power to enact fee-shifting offer of settlement laws. If CJRA could be read as an attempt to repeal the limitation on court rulemaking and authorize the federal courts to make laws governing conduct extrinsic to the litigation process, it would be unconstitutional. Thus, the Eastern Texas Plan, not only by disregarding its status as an inferior court but also by enacting substantive law, twice offended principles of separation of powers embedded in the Rules Enabling Act of 1988, performing the surprising feat of overreaching in one utterance the counterpart constitutional authorities of Congress and the Supreme Court.

\section{FEE-SHIFTING RULES OF COURT FORBIDDEN BY CONGRESS: THE UNCERTAIN VALIDITY OF RULE 68}

Even if fee-shifting rules were not "substantive" for purposes of the Rules Enabling Act and beyond the legislative competence of an Article III institution, there is a further problein with the Eastern Texas Plan that such rules are forbidden by an unrepealed act of Congress. The Court has recently affirmed that by the 1853 Fee Act, "Congress ineant to impose rigid controls on cost-shifting in federal courts."278 It has also held, contrary to the Eastern Texas Plan, that expert witness fees are not taxable, even when Congress has authorized the shifting of attorneys' fees. ${ }^{279}$ The Sixth Circuit in invalidating a local rule with a fee-shifting provision reseinbling that of the Eastern District of Texas reviewed the Supreme Court decisions and concluded thus:

In Crawford, the issue before the Court was whether federal courts could require losing parties to pay compensation for the prevailing party's expert witness fees in excess of the $\$ 30.00$ per day provided for in 29 U.S.C. $\S 1821$. The Court held the district court had no such power. The Court noted that "Title 28 U.S.C. $\S 1920$ now embodies Congress' considered choice as to the kinds of expenses that a federal court may tax as costs against the losing party," and that "the comprehensive scope" of the 1853 Fee Act and the faithfulness with which Congress has followed it

277. S. 672, 104th Cong., 1st Sess., tit. III, § 304 (1995).

278. Crawford Fitting Co. v. J.T. Gibbons, Inc., 482 U.S. 437, 444 (1987).

279. West Virginia Univ. Hosp., Inc. v. Casey, 499 U.S. 83 (1991). 
demonstrated to the Court "that Congress meant to impose rigid controls on cost-shifting in federal courts." The Court went on to hold that to read Fed. R. Civ. P. 54(d) as "a separate source of power authorizing district courts to tax costs and expenses not enumerated in $\S 1920$ " rendered that section superfluous, in that courts could ignore it whenever they wished. Therefore, the Court rejected such a reading and ruled that absent express statutory authorization to the contrary, section 1920 defined the term "costs" as used in Fed. R. Civ. P. 54(d).

... If a general rule may be read in Alyeska Pipe Line and its progeny, it is that the Supreme Court will not allow itself or other federal courts to vary the uniform scheme of costs and fees as set forth in the 1853 Fee Act, other than those narrowly defined circumstances of cases involving bad faith or abusive litigation, disobedience of court orders or the common fund doctrine. ${ }^{280}$

If courts cannot nake fee-shifting law even in the course of deciding cases, what of Rule 68? It seems certain that the Eastern Texas Plan was an outcoine of years of debate over the proper content of that rule. That debate has been conducted with little, if any, regard for the constitutional and statutory limits of the rulemaking power. Arguably, Rule 68 was invalid, if not because it was nnconstitutionally promulgated, then because it violated a substantive act of Congress that procedural rulemakers were not commissioned to supersede. It has become timely to consider such issues.

As originally promulgated in 1938, Rule 68 enabled defendants to avoid hability for taxable costs, and to impose liability for taxable costs on a plaintiff, by making an offer of judginent that is more favorable than that obtained by the plaintiff after trial. This was a rule of hittle consequence because the costs taxable under section 1920 in 1938 were inodest. ${ }^{281}$ The rule imposed an imcentive to settle on plaintiffs, but an incentive so minuscule as to be

280. Tiedel v. Northwestern Mich. College, 865 F.2d 88, 93-94 (6th Cir. 1988).

281. Section 1920 lists six categories of taxable costs. These include fees of the clerk and inarshal, fees of the court reporter for transcripts obtained for use at trial, witness fees, printing and copying charges, docket fees, and compensation of special court officers such as interpreters. 28 U.S.C. $\S 1920(1)$-(6) (1994). There is nothing in $\S 1920$ to suggest shifting of attorneys' fees. See id. On the history of payment of costs, see Philip M. Payne, Costs in Common Law Actions in the Federal Courts, 21 VA. L. REv. 397 (1935). The Court in Marek noted that there were in 1938 some federal laws shifting fees as "costs." Marek v. Chesny, 473 U.S. 1, 8-9 (1985). 
almost inconsequential. The rule was almost inoperative for four decades. ${ }^{282}$

The rule was not in any useful sense a rule of "pleading and practice" as the 1934 Act authorized the Court to inake. ${ }^{283}$ The rule had little to do with what happens in court or between judges and lawyers or their clients; it did nothing to increase the likelihood that a court's judgment would be the product of a correct apphication of law to accurately determined facts. Its apparent aim was to induce settlement out of court without regard for the inerits. Social peace and the informal resolution of disputes are, of course, positive values, but they are not aspects of due process of law and are not integral to the work of the courts. The pursuit of social peace is assuredly a proper object of ordinary Article I legislation, at least with respect to matters that are within federal cognizance, but it is not a proper object of legislative enactments by politically independent, invulnerable Article III courts.

The facts that the origimal Civil Rules Advisory Committee recommended Rule 68 in 1938 and that the Supreme Court promulgated it create a presumption in favor of its validity. ${ }^{284}$ To the extent that the original Rule 68 conflicted with section 1920 , it could have superseded that 1853 legislation, if, but only if, it was a rule of "pleading and practice" that the Court was authorized to promulgate by the 1934 Act. But the issue of Rule 68's cliaracter, so far as it appears, was never discussed by the rulemakers of 1938. Charles Clark, as Reporter for the Committee, had staff responsibility for keeping the committee within its prescribed role; admirable as his performance as reporter was, he was sometimes careless im failing to call to the committee's attention statutory and constitutional limits on its autliority. For example, the legislative

282. There were no reported federal cases before 1978 in which fees were treated as part of the costs shifted under Rule 68. Marek, 473 U.S. at 20-21 (Brennan, J., dissenting.); cf. Delta Air Lines v. August, 450 U.S. 346 (1981).

283. The 1934 Act authorized the Court to "prescribe, by general rules . . . the forms of process, writs, pleadings, and motions, and the practice and procedure [of the district courts of the United States] in civil actions at law." Act of June 19, 1934, ch. 651, 48 Stat. 1064.

284. See Burlington Northern R.R. v. Woods, 480 U.S. 1, 6 (1987); Peter Westen \& Jeffrey S. Lehman, Is There Life for Erie Afier the Death of Diversity?, 78 MICH. L. REV. 311, 364 (1980); cf. Ralph U. Whitten, Erie and the Federal Rules: $A$ Review and Reappraisal After Burlington Northern Railroad v. Woods, 21 CREIGHTON L. REv. 1, 1-2 (1988) (arguing that the Supreme Court considers Federal Rules-state law conflicts too lightly). 
history of the 1934 Act gave assurance that no statute of limitations would be promulgated pursuant to it. ${ }^{285}$ Yet Clark advocated that Rule $3^{286}$ be drafted as a provision of limitations law fixing the filing of a complaint as a commencement of an action for the purpose of its timeliness; such a rule would have been at odds with the limitations laws of states requiring that, in addition to filing, a summons had to be served on the defendant within the statutory period. ${ }^{287}$ Such a rule would not have been a rule of "practice and pleading" such as the 1934 Act authorized the Court to promulgate; and had the Act authorized such a rule, it would have been of dubious constitutionality. Clark's recommendation was wisely resisted by the chairnan of the Committee on the ground that such a rule would exceed the committee's authority under the Act. ${ }^{288}$ Clark's text of Rule 3 was retamed, but merely for use as a measure of the timeliness of other events occurring at later stages in the litigation, such as the filing of a motion for summary judgment. ${ }^{289}$

There was no comparable consideration of Clark's proposed Rule 68. Had there been, perhaps the Committee sitting in 1938 would have considered the limits of rule enablement and also the interface of the Rules with section 1920. As noted above, the 1938 Rules contained a provision in Rule 54 superseding the mandatory language of section 1920, a supersession to which Congress acceded in $1948 .{ }^{290}$ Perhaps Rule 68, like Rule 54, can be taken as liaving superseded section 1920 to the minor extent that there was conflict witl it. ${ }^{291}$ The difficulty with using the supersession clause to save Rule 68 is that the clause applies only to genume rules of "practice and procedure," not at all to rules "abridging or modifying" substantive riglits. But as long as no more was at stake

285. S. REP. No. 1174,69 th Cong., 1st Sess. 9 (1926).

286. FED. R. CIV. P. 3 still provides that "[a] civil action is commenced by filing a complaint."

287. E.g., Ragan v. Merchants Transfer \& Warehouse Co., 337 U.S. 530, 531 (1949)

(discussing KAN. GEN STATS. 1935, \& 60-306).

288. See Burbank, supra note 39 , at $1159-1160$ \& n.619.

289. FED. R. CIV. P. 56.

290. See supra note 225 and accompanying text.

291. The advisory committee's note to Rule 54(d) refers to the statutory predecessor of $\S 1920$ as "unaffected by this rule." FED. R. CIV. P. 54(d) advisory committee's note. Curiously, there is no reference to the statute in the advisory committee's note to Rule 68. 
than the peanuts that were taxable costs under the statute, it was worth no one's trouble to raise the issue.

Beginning in the 1970s, perhaps at the behest of Chief Justice Warren Burger, ${ }^{292}$ the rulemakers began to reconsider Rule 68 and proposed to put some real teeth in it. Drafts were circulated that would have added attorneys' fees to the taxable costs paid by a plaintiff rejecting a favorable offer ${ }^{293}$ These proposals gave rise to a storm of controversy, ${ }^{294}$ with strong criticism coming from those most concerned with protecting the interests of plaintiffs. ${ }^{295}$ Again curiously underdeveloped in that debate, as it had been in the 1930s, was the question whether the Court had been empowered by the Rules Enabling Act to legislate a fee-shifting rule at odds with section 1920, or whether if the Act did purport to confer such power, it was an unconstitutional delegation of an Article I power and responsibility to an Article III imstitution. ${ }^{296}$ Nevertheless, without forcing these issues, those protesting the rulemakers' drafts prevailed with the committee, who in 1985 tabled further consideration of Rule 68. The imbroglio in which the Committee involved itself ought be taken as instruction that the issues raised by offer-of-settlement rules have too much pohitical content to be wisely managed by rule of court. ${ }^{297}$

Meanwhile, however, the Supreme Court in Marek $v$. Chesny ${ }^{298}$ partially effected Chief Justice Burger's objective by holding that Rule 68 cuts off the recovery of post-offer attorney fees under a fee-shifting statute that described such fees as costs taxable under section $1920 .^{299}$ This did not include all the stat-

292. Roy Simon, The Riddle of Rule 68, 54 GEO. WASH. L. REV. 1, 4 n.7 (1985) (noting the Chief Justice's lobbying efforts in the 1980s on behalf of a stronger Rule 68).

293. Id. at 10-12, 17.

294. Id. at $17-19$.

295. See Note, The Conflict Between Rule 68 and the Civil Rights Attomeys' Fees Statute: Reinterpreting the Rules Enabling Act, 98 HARV. L. REV. 828, 846 (1985). See generally Stephen B. Burbank, Proposals to Amend Rule 68-Time to Abandon Ship, 19 U. MICH. J. L. REF. 425 (1986) (criticizing the advisory committee's repeated efforts to reform Rule 68 ).

296. See Marek v. Chesny, 473 U.S. 1, 37-38 (1985) (Brennan, J., dissenting). But see Burbank, supra note 295 , at $430-31$.

297. See, e.g., Geoffrey P. Miller, An Economic Analysis of Rule 68, 15 J. LEGAL STUD. 93 (1986) (examining the wealth redistribution effects of Rule 68).

298. 473 U.S. 1 (1985); see also Roy D. Simon, Jr., The New Meaning of Rule 68: Marek v. Chesny and Beyond, 14 N.Y.U. Rev. L. \& Soc. CHANGE 475 (1986) (examining Marek and its effect of revitalizing Rule 68).

299. See Marek, 473 U.S. at 43-48 (appendix to Justice Brennan's dissent). 
utes in which Congress had provided for fee-shifting because soinetimes it has characterized its fee-shifting as part of the costs, and sometimes it has not. There was no visible explanation for these differing choices of legislative diction. And, of course, the traditional American rule ${ }^{300}$ prevails in the absence of any explicit direction froin Congress. The result of Marek is a bizarre pattern; Rule 68 has real bite in civil rights cases $^{301}$ and other cases arising under statutes providing for taxation of fees as part of the section 1920 costs, but inany plaintiffs asserting federal rights that are explicitly subject to fee-sliifting are not subject to the threat of an offer of settleinent because the statutes they invoke do not contam the magic words "as costs." Thus, while plaintiffs in civil rights cases are exposed to fee-shifting under Rule 68 because the civil rights legislation shifts fees as part of the costs, plaintiffs in an action brouglit under the Fair Housing $\mathrm{Act}^{302}$ or the Equal Pay $\mathrm{Act}^{303}$ are not so exposed because those acts, while providing for fee-shifting, fail to denote thein as "costs."304 As a question of separation of powers, this result is not seriously troubling because the Marek scheine rests on an interpretation of the Civil Riglits Act. While the interpretation of the Civil Riglts Act may seein tortured, the Court has not clained for itself the power on its own to legislate a fee-shifting offer-of-settlement rule.

In deciding Marek, the Court silently upheld Rule 68. The court of appeals lad decided that Rule 68 if interpreted as a feeshifting rule would exceed the authority conferred by the Rules Enabling Act. ${ }^{305}$ The three dissenters in the Supreme Court agreed. ${ }^{306}$ The inajority did not address the issue because it rehed

300. Arcambel v. Wiseman, 5 U.S. (5 Dall.) 306 (U.S. 1796). See generally John Leubsdorf, Toward a History of the American Rule on Attorney Fee Recovery, LAw \& CONTEMP. PROBS., Winter 1984, at 9 (providing a historical analysis of the development of the American rule).

301. The problem arises from the interface of Rule 68 with the Civil Rights Attorneys' Fees Awards Act of 1976, 42 U.S.C. § 1988 (1994). See Victoria C. Choy, Note, The Impact of Proposed Rule 68 on Civil Rights Litigation, 84 Colum. L. REv. 719, 739-42 (1984); Note, supra note 295 (examining the conflict between Rule 68 and $\S$ 1988).

302. 42 U.S.C. $\S \S 3601-3619$ (1994).

303. 29 U.S.C. \& 206 (1988).

304. For a compilation of the fee-shifting statutes, see the appendix to Justice Brennan's dissenting opinion in Marek. Marek v. Chesny, 493 U.S. 1, 22, 43-51 (1985).

305. Chesny v. Marek, 720 F.2d 474, 479 (7th Cir. 1983).

306. Marek, 493 U.S. at 15 (Brennan, J., dissenting) (joined by Marshall, J. and Blackmun, J.). 
on the Civil Rights Act rather than the Rules Enabling Act for its legitimation of the fee-shifting it imposed. The case is not authority for the existence of a power in the Supreme Court to enact the rule embodied in the Eastern Texas Plan which would shift fees when there is no color of congressional authority to do so, but to the contrary indicates that any judge-made legislation bearing on the shifting of fees must be fully and carefully reconciled to the utterances of Congress, such as those einbodied in the Fees Act.

In 1992, the Civil Rules Committee again considered Rule 68, this time working off the draft suggested by Judge William Schwarzer, Director of the Federal Judicial Center. ${ }^{307}$ This proposal was in one sense less politically sensitive and hence less substantive than the old rule because it gave a similar power to extend offers to plaintiffs, thus equalizing the incentives to settle. Yet it was clearly subject to the saine objection as the old rule as a misuse of the rulemaking power. Rule 68 ought to be repealed; this would have the benign effect of eliminating the crazy quilt created by the decision in Marek and would place the issue before Congress, where it belongs, and where it now pends. ${ }^{308}$

In a significant respect, the initiative of Chief Justice Burger and the Advisory Committee on Civil Rules with respect to Rule 68 was a product of its time. As noted above, there was a time im the mid-1960s when judicial rulemaking seemed to be the object of universal acclaim. In 1965, the Court decided Hanna v. Plu$m e r{ }^{309}$ laying to rest concerns that the Rules would be made to yield on a wide range of matters to state law. ${ }^{310}$ In 1966, an amendnient to Rule 23 vastly enlarged the utility of the class action device, with significant radiating consequences for the worth

307. See Schwarzer, supra note 235. Judge Schwarzer's plan was based in part on theoretical work reported in Symposium, Attorney Fee Shifting, LAW \& CONTEMP. PROBS., Winter 1984, at 1. See also John J. Donahue, III., The Effects of Fee Shifting on the Settlement Rate: Theoretical Observations on Costs, Conflicts, and Contingency Fees, LAW \& CONTEMP. PROBS., Summer 1991, at 195 (using economic inodels to evaluate the effects of fee shifting on the likelihood of settlement).

308. See S. 672, 104th Cong., 1st Sess. (1995).

309. 380 U.S. 460 (1965).

310. See e.g., Bernard C. Gavit, States Rights' and Federal Procedure, 25 IND. L.J. 1, 1 (1949) (arguing that the Erie doctrine should not be extended "into the field of federal procedure"); Edward L. Merrigan, Erie to York to Ragan-A Triple Play on the Federal Rules, 3 VAND. L. REV. 711, 725 (1950) ("[T]here are many . . Rules . . . which are susceptible to rejection or delimitation as a result of the current extensions of the Erie doctrine to inatters which heretofore have been considered strictly procedural."). 
of numerous claims and defenses. ${ }^{311}$ Work commenced on the Federal Rules of Evidence. Few questioned any of these developments as possible overreachings. It was easy to think that courts could legislate on almost any subject if there was any remote connection to judicial administration.

Times have changed. Beginning with the rejection of the Federal Rules of Evidence by Congress in 1972,312 there has been growing friction over procedural lawmaking. Several wise observers expressed caution about the absence of democratic representation in the process. ${ }^{313}$ The 1988 amendments to the Rules Enabling Act took some modest steps, as many perhaps as can be taken consistently with the elitist prenrises of Article III, to open the process to influence by those affected by rulemaking decisions. ${ }^{314}$ Congress in the 1980s became less deferential, amending Rule $4^{315}$ and Rule $35^{316}$ on its own, almost deciding to lay aside the promulgated amendments to Rule 26 in $1993 .{ }^{317}$ Also in the 1980 s, elements of the bar became exercised about the 1983 amendment of Rule $11^{318}$ and the revision of Rule 68 as proposed in the 1983 and 1984. Bar sentiments reached a crescendo in 1993 over the amendments of the discovery rules. ${ }^{319}$ On the aca-

311. For an account of the amendment and its effects, see Arthur R. Miller, Of Frankenstein Monsters and Shining Knights: Myth, Reality, and the "Class Action Problem," 92 HARV. L. REV. 664 (1979).

312. See Federal Rules of Evidence Act, Pub. L. No. 93-595, 88 Stat. 1926 (1975).

313. See Ronan E. Degnan, The Law of Federal Evidence Reform, 76 HARV. L. REV. 275, 282-301 (1962); Lesnick, supra note 180, at 582; WEINSTEIN, supra note 116, at $101-04$.

314. Act of Nov. 19, 1988, Pub. L. No. 100-702, 102 Stat. 4642; see Making Rules, supra note 55 , at 2076.

315. Act of Jan. 12, 1983, Pub. L. No. 97-462, 96 Stat. 2527; see Kent Simclair, Service of Process: Rethinking the Theory and Procedure of Serving Process Under Federal Rule 4(c), 73 VA. L. REV. 1183, 1194-1212 (1987) (describing the evolution of Rule 4); see also Linda S. Mullenix, The New Federal Express: Mail Service of Process Under Amended Rule 4, 4 REv. LITIG. 299 (1985) (examining the courts' treatment of problems that arose under the 1983 Rule 4 amendments during the two years following their enactment); Ralph U. Whitten, Separation of Powers Restrictions on Judicial Rulemaking: A Case Study of Federal Rule 4, 40 ME. L. REv. 41 (1988) (examining the restramts that the separation of powers doctrine imposes on supervisory rulemaking by the Supreme Court in the context of Rule 4). On later efforts to revise Rule 4, see Paul D. Carrington, Continuing Work on the Civil Rules: The Summons, 63 NOTRE DAME L. REv. 733 (1988).

316. Anti-Drug Abuse Act of 1988, Pub. L. No. 100-690, 102 Stat. 4181, 4401.

317. For a fuller account, see Carrington, supra note 236.

318. For discussion of the complaints, see 2 WRIGHT \& MiLLER, supra note 79, 1332 (1990).

319. Charles W. Sorenson, Jr., Disclosure Under Federal Rule of Civil Procedure 
demic side, as noted, some commentators concluded that some of the rules should be rewritten to have different apphications to different classes of cases, according to the substantive nature of claims or defenses presented; ${ }^{320}$ this was a feat that Congress would have to perform. Accordingly, it seems fair to say that the scheme established by the Rules Enabling Act is presently embattled. ${ }^{321}$

Given this sea change, it is likely that a prudent Supreme Court would be cautious about claiming extravagant powers to enact fee-shifting law derived from the sparse language of the Rules Enabling Act. It is more likely at present than in the past to observe scrupulously the bounds to its lawmaking authority and responsibility. ${ }^{322}$ It can reasonably be expected wisely to avoid being thrust into the cockpit of factional politics raging over the extent to which individuals should be encouraged or discouraged to brimg their grievances to federal courts. A fee-shifting offer-ofsettlement rule not rooted in a statute such as section 1920, or the fee-shifting statutes such as those relied upon in Marek, is therefore one that the Court would not itself claim the power to promulgate, at least in the absence of exphicit authorization from Congress.

The requirement that judge-inade legislation be nonsubstantive-the requirement explicit in the Rules Enabling Act-must be implicit in CJRA. There is nothing in CJRA suggesting that Congress was at the time of its enactment indifferent to this restraint on the delegability of its power and authority to politically insensitive Article III imstitutions. Nor is there a word in CJRA suggesting an intent to authorize the modification of section 1920. It caimot be casually inferred that Congress intends others to perform its role, especially perhaps when the others have their own constitutional roles and limitations, as Article III courts do. If and when Congress explicitly authorizes federal courts to codify fee-

26(a)_“"Much Ado About Nothing?" 46 HASTINGS L.J. 679, 726-27 (1995).

320. See supra notes 253-54 and accompanying text.

321. See generally Paul D. Carrington, The New Order in Judicial Rulemaking, 75 JUDICATURE 161 (1991); Marcus, supra note 56; Linda S. Mullenix, Hope Over Experience: Mandatory Informal Discovery and the Politics of Rulemaking, 69 N.C. L. REV. 795, 855-57 (1991).

322. For an example of such scruples, see Omni Capital Int'l v. Rudolf Wolff \& Co., 484 U.S. 97 (1987) (holding that the Court did not have authority to create its own rule authorizing service of process). 
shifting laws in contravention of the ancient Fees Act, it will be time to consider fully the constitutional considerations advanced here; but ineanwhile, it is correct to conclude that CJRA does not authorize local plans to shift or limit fees of lawyers or their expert witnesses, or otherwise tinker with the provisions of section 1920.

\section{The Limits of NATIONAL Legislative POWER UNDER ARTICLE I}

Eastern Texas seems also bent on violating the principles of our federalisin. Like the separation of powers principles discussed above, the federalism principle is also expressed in ancient and controlling federal legislation that remains untested. Now embodied in section 1652, the Rules of Decision Act-originally Section 34 of the Judiciary Act of 1789-requires federal courts to regard "the laws of the several states" as the rules of decision in civil actions "except where the Constitution or treaties of the United States or Acts of Congress otherwise require."323 Explicit as was the attention given in the Constitution to limiting the legislative power of Congress, the principle of the Rules of Decision Act was an almost necessary implication of Article $\mathrm{I}^{324}$ It belonged in the first Judiciary Act in the same way that the provision forbidding the promulgation of rules of court modifying or abridging substantive rights belonged in the Rules Enabling Act. ${ }^{325}$ With respect to the problein at hand, both are cautionary surplusage. ${ }^{326}$

323. The history of this provision has been the subject of extended debate. See, e.g., WILFRED J. RITZ, REWRITING THE HISTORY OF THE JUDICIARY ACT OF 1789: EXPOSing Myths, Challenging Premises, ANd Using New Evidence (Wythe Holt \& L. H. LaRue eds., 1990); Patrick J. Borchers, The Origins of Diversity Jurisdiction, the Rise of Legal Positivism, and a Brave New World for Erie and Klaxon, 72 TEX. L. REV. 79 (1993); Charles Warren, New Light on the History of the Federal Judiciary Act of 1789, 37 HARV. L. REV. 49 (1923).

324. See Martin H. Redish \& Carter G. Phillips, Erie and the Rules of Decision Act: In Search of the Appropriate Dilemma, 91 HARV. L. REV. 356, 358 (1977); Martin H. Redish, Federal Common Law, Political Legitimacy, and the Interpretative Process: An "Institutionalist" Perspective, 83 Nw. U. L. REV. 761, 763 (1989).

325. For recent exegesis on the Act, see Burbank, supra note 103; William A. Fletcher, The General Common Law and Section 34 of the Judiciary Act of 1789: The Example of Marine Insurance, 97 HARV. L. REV. 1513 (1984).

326. The Rules of Decision Act is declared to be a "truisin" by one commentator. Peter Westen, After "Life for Erie"-A Reply, 78 Mich. L. REV. 971, 982 n.45 (1980). There is a rich academic hiterature on the Rules of Decision Act, chiefly bearing on its effect as a limitation on judge-made law. See, e.g., Martha A. Field, Sources of Law: The 
As the reader knows, a cloud was placed over the Act in 1842 by the decision of the Court in Swift v. Tyson, ${ }^{327}$ which interpreted "laws of the several states" to include only statutes and claimed on behalf of the Court the power to fashion a general federal common law applicable to cases litigated in federal court and not governed by state legislation. Justice Stephen Field was the first to call attention to the fact that the Court was fashioning legal doctrine that the Congress itself was not empowered to enact; he foretold that the doctrine of Swift $v$. Tyson would "die among its worshippers." 328 In 1909, John Chipman Gray publisled his scorching attack on the intellectual premises of Swift. ${ }^{329}$ The interpretation was again assailed in 1928 by Justice Holmes, who described it as an "unconstitutional assumption of powers by the Courts of the United States. ${ }^{1330}$ It was at last reversed in Erie, with Justice Brandeis for the Court emphasizing that "[i]f only a question of statutory construction were involved, we should not be prepared to abandon a doctrine so widely applied throughout nearly a century. But the unconstitutionality of the course pursued has now been made clear and compels us to do so."331

The Erie doctrine went through an extended period of reformulation. At one time, it seemed likely to destroy the Federal Rules of Civil Procedure by requiring the application of state procedural law at every significant turn. The threat was posed by Justice Frankfurter's fornulation of an "outcome determinative test" requiring that state laws be applied in federal litigation if they might affect the outcome. ${ }^{332}$ Henry Friendly described this test as "overly entlusiastic";333 Charles Clark described it as taking a good idea "to an absurd extreme."334 In reaction against

Scope of Federal Common Law, 99 HARV. L. REV. 883 (1986); Thomas W. Merrill, The Common Law Powers of Federal Courts, 52 U. CHI. L. REV. 1 (1985); Redish \& Phillips, supra note 324; Steven D. Smith, Courts, Creativity and the Duty to Decide a Case, 1985 U. ILL. L. REV. 573 (1985).

327. 41 U.S. (16 Pet.) 1 (1842).

328. Baltimore \& Olio R.R. v. Baugl, 149 U.S. 368, 403 (1893) (Field, J., dissenting).

329. John ChIPMAN GRAY, ThE NATURE AND SOURCES OF THE LAW 251-56 (2d ed. 1972).

330. Black \& White Taxicab \& Transfer Co. v. Brown \& Yellow Taxicab \& Transfer Co., 276 U.S. 518, 533 (1928) (Holmes, J., dissenting).

331. Erie R.R. v. Tompkins, 304 U.S. 64, 77-78 (1938) (footnote omitted).

332. Guaranty Trust Co. v. York, 326 U.S. 99, 109 (1945).

333. Henry J. Friendly, In Praise of Erie-And of the New Federal Common Law, 39 N.Y.U. L. REV. 383, 402 (1964).

334. Cliarles E. Clark, Federal Procedural Reform and States' Rights: To a More Per- 
this period of "over-enthusiasm," some questioned the constitutional basis for the Erie decision, ${ }^{335}$ but the prevailing view among contemporary commentators is that Erie does indeed rest on a constitutional base that, like the separation of powers principles discussed above, remams untested and indeterminate. ${ }^{336}$

Justice Brandeis was not exphicit in explaining the constitutional principle he invoked; he almost seemed to rely on the Tenth Ainendment as its source. The Constitution, however, was again referred to as a basis for the decision in Bernhardt v. Polygraphic Co. of America, ${ }^{337}$ which apphed Vermont law rather than the Federal Arbitration Act of 1925 to determine the arbitrability of a local dispute. Justice Frankfurter's concurring opinion in that case explamed the constitutional problem to be the absence of any authorization in Article I for the federal government to impose its substantive enactnients on hitigants on no basis other than their presence in a federal court; ${ }^{338}$ he did not rely upon the Tenth Amendnient for the principle that the federal government is one of limited power and responsibility. This was also the point acknowledged by the Court in Hanna v. Plumer, ${ }^{339}$ its decision laying to rest concerns that the Federal Rules of Civil Procedure could not be applied to cases to be decided accordimg to state law. ${ }^{340}$ Frankfurter's Bernhardt proposition has since gained general acceptance, although there have been no recent occasions for its application.

Although given little emphasis in the Court's brief utterances regarding the constitutional basis of Erie, there likely is an equal protection consideration lending added significance to the absence

fect Union, 40 TEX. L. REv. 211, 220 (1961).

335. See, e.g., Charles E. Clark, State Law in the Federal Courts: The Brooding Omnipresence of Erie v. Tompkins, 55 YALE L.J. 267, 273 (1946); Philip B. Kurland, Mr. Justice Frankfurter, The Supreme Court and The Erie Doctrine in Diversity Cases, 67 YALE L.J. 187, 188-204 (1957); see also Alfred Hill, The Erie Doctrine and The Constitution, 53 Nw. U. L. REV. 427, 428 (1958) (positing that "the post-Erie line of cases las taken an unduly rigid course which does not adequately allow for the variety and complexity of the problems encountered in diversity litigation").

336. John Hart Ely, The Irrepressible Myth of Erie, 87 HARv. L. REv. 693, 700-06 (1974); Friendly, supra note 333, at 384-98; Henry M. Hart, Jr., The Relations Between State and Federal Law, 54 COLUM. L. REv. 489, 509-10 (1954); Westen \& Lehman, supra note 284 , at 338-44, 353-56.

337. 350 U.S. 198 (1956).

338. Id. at 208.

339. 380 U.S. 460 (1965).

340. Id. at 471-72. 
of authorization in Article I. It is irrational to impose two different bodies of substantive law on an event or transaction solely on the basis of which of two courts having concurrent jurisdiction over a dispute arising from that event or transaction comes to exercise that jurisdiction; arbitrarily discriminatory results occur because of the citizenship of the disputants opening or closing the door to the federal court. This consideration serves to explain why the Constitution does not enumerate annong the powers of Congress the making of substantive law to govern disputes brought to the federal courts. To legislate conditionally on a happenstance of the forum selected can effectively serve no purpose of the national government, and disserves the purposes of state government by interfering with even-handed apphication of state law.

Yet, as Hanna v. Plumer demonstrated and as all acknowledge, the federal government does retain substantial control over the conduct of proceedings in its courts. The line to be drawn to limit federal power resembles, but is not necessarily the same as, the line defining the limits of pernissible delegation of legislative authority to Article III institutions. If a law in question bears on the process of applying law to fact, on events occurring in the federal courthouse as part of that process, or on relations between federal courts and counsel, there can be no question of the validity of a federal enactment. But as the relationship between a purportedly procedural law and the constitutional function of the Article III institution becomes attenuated, a serious question begins to arise.

Thus, in the context of facts such as those presented in Erie, if Congress were to enact a statute limiting recovery of trespassers to land to damages intentionally caused by the landowner, the statute would exceed the powers of Congress enumerated in Article $\mathrm{I}$, and would neither be binding on state courts nor be given effect by federal courts. Congress has the undoubted power to regulate the tort hability of interstate carriers to trespassers on their rights-of-way because the presence of interstate commerce provides a basis in Article I for such legislation. Or to take a contemporary instance, if Congress were to enact a statute requiring courts to issue mjunctions forbidding school children from taking guns to school, ${ }^{341}$ the legislation would not be binding on

341. United States v. Lopez, 115 S. Ct. 1624 (1995). 
state or federal courts, at least not in the absence of a demonstrated connection between guns in school and one of the responsibilities of Congress enumerated in Article I. Neither of these imaginary laws would be saved by restricting their operation to cases brought to the federal courts in the exercise of the diversity jurisdiction. Indeed, for the reasons stated above, such a discrimination based on the happenstance of state citizenships of parties would elevate constitutional concerns. No coherent federal policy would be achieved while state law on the subject would be made incoherent.

By the same token, Congress has no power to enact a law imposing a general offer-of-settlement rule such as Rule 68 on all disputes arising between citizens or residents of the United States. If hyperlexis is a national problem, it is not one that Congress can address so directly without overstepping the limits of its powers 1mder Article I. Nor can Congress regulate all contingent fee contracts between lawyers and their chents without regard for the relation or lack of relation between the legal services engaged and any of the enumerated powers of Congress. Nor can it reverse the American rule and adopt for all cases, state or federal, the English rule that losers pay winners' attorneys' fees rule in all cases because the general rule regarding fee-shifting is not within the enumerated powers of Congress; it is, therefore, a matter generally reserved to the states. The Court has exphcitly acknowledged the primacy of state law with respect to fee-shifting in diversity litigation. ${ }^{342}$ No donbt laws regulating contingent fees or adopting the Englisl rule could be constitutionally enacted by Congress if applicable ouly to disputes arising from the enforcement of federal law or as mcidents of a regulation of interstate commerce in a field such as products liability.

Less clear is the power of the federal government to enact a fee-shifting offer-of-settlement rule applicable to all cases litigated in federal courts, without regard to the source of the substantive rights being contested. The power of Congress to attach fee-shifting rules to the federal claims and defenses it creates can scarcely be questioned. But the same reasoming advanced above to explain why the enactment of fee-shifting rules is for Congress, not for the Court under the Rules Enabling Act, can also be marshalled to explam wliy, with respect to diversity cases, the issue must be

342. Alyeska Pipeline Serv. Co. v. Wilderness Soc'y, 421 U.S. 240, 259 n.31 (1975). 
controlled by state rather than federal law. The policy is one over which state legislatures, not Congress, have the final say. ${ }^{343}$ Feeshifting rules arguably have too little bearing on the courthouse conduct of federal litigants and too much bearing on the value of the substantive riglits and defenses created by state law to be mere features of federal judicial administration. If, for example, the state of Texas seeks to encourage its citizens to bring their grievances over alleged spite fences, defamations, or repudiations of unilateral contracts to courts, it is not the place of any brancl of the federal government to prevent such a public policy by removing the litigation to a federal court in which stern mcentives will be imposed to induce the parties to settle witliout an adjudication on the inerits.

A recent example of the problem is S.A. Healy Co. v. Milwaukee Metropolitan Sewerage District. ${ }^{344}$ The Seventl Circuit there affirmed the application of a Wisconsin fee-shifting offer-ofsettlement rule benefitting plaintiffs to a plaintiff who lad invoked diversity jurisdiction. The court concluded that the Wisconsin law was substantive and not in conflict witl Rule $68 . .^{345}$ The court noted that failure to apply the Wisconsin law would give rise to forum-slopping opportumities of the sort that the Erie principle souglit to minimize and did nothing to "impair the integrity of federal procedure." ${ }^{346}$ If Rule 68 had been read to forbid feeshifting offer-of-settlement rules for plaintiffs, the court would then have liad to decide whether Rule 68 was authorized by the Rules Enabling Act and, if so, whether Congress had such a power to confer on the Court the power as rulemaker. This was the issue avoided by the Court in Marek.

While that issue remains doubtful, there seems less doubt about a federal law that applies ouly to diversity cases. Thus, the proposed Common Sense Law Reform Act of $1995^{347}$ contained at least one provision that would seem to violate the constitutional principle announced by Justice Brandeis. It proposed to enact the

343. See, e.g., Wright, supra note 258 at 571-74.

344. 60 F.3d 305 (7th Cir. 1995).

345. Id. at $310-11$.

346. Id. at 310 .

347. This proposal first appeared in the report of the Council on Competitiveness Recommendation 36 and in H.R. 10, 104th Cong., 1st Sess. $\S 101$ (1995). For comment on the fee-shifting provisions of the act, see Carl Tobias, Common Sense and Other Legal Reforms, 48 VAND. L. REV. 699, 729-31 (1995). 
Enghish rule for diversity cases brought to federal court by plaintiffs. Happily, this idea seems to have been abandoned when its proponents recognized how unsuitable a proposal it was. It presented plaintiffs with a premier opportunity to engage in forumshopping; those with proinising cases would have coinpelling reason to seek federal jurisdiction. Sorne plaintiffs would win large fee awards because they were fortunate enough to be able to invoke federal jurisdiction; others would not have access to such awards for the arbitrary reason that they were citizens of the wrong state. Plaintiffs intimidated by the prospect of paying the defendants' attorneys' and expert witnesses' fees would simply avoid federal courts. No coherent federal policy would be achieved, and state law would be significantly disrupted. The incoherence would be less if the fee-shifting rule also applied to removed cases, but that would make the removal jurisdiction the battleground that it was a century ago while magnifying the disruption of state law.

I diffidently conclude that Congress may lack power to enact a fee-shifting rule designed to induce settlement of all civil cases in federal courts, and almost certainly lacks the power to enact a fee-shifting rule fashioned to induce settlement only of diversity cases. $^{348}$ If CJRA is found to authorize plans having the latter effect, I would expect the Court to hold it pro tanto unconstitutional.

\section{CJRA AND THE EFFICACY OF STATE LAW}

Congress can and sometimes does provide for fee-shifting in actions brought to enforce rights it creates. It chose to do so when it enacted the Clean Water Act, ${ }^{349}$ which provided the subject of the dispute in Friends of the Earth. The district court recognized that its Plan, if applied to the plaintiff in that case, would partially frustrate the purpose of the statute and wisely concluded that it should therefore be withheld from operation in Clean Water Act

348. Caution is indicated in part because the Court has been so deferential to Congress on issues of federalisin, to the point indeed of raising an issue of a possible neglect of duty. Willian W. Van Alstyne, The Second Death of Federalism, 83 MicH. L. REv. 1709 (1985). The recent Lopez case, cited supra note 341, is heartening in showing that the Court is still a responsible force in this field. See United States v. Lopez, 115 S. Ct. 1624 (1995).

349. 33 U.S.C. § 1365(d) (1995). 
cases. ${ }^{350}$ What the court failed to acknowledge is that its rule will in every instance of its application have a similar substantive effect on rights and defenses established either by Congress, by a state, or by a foreign country whose law is applicable by reason of a clioice of law made pursuant to state law. For a federal court to so modify substantive rights created by state law is contrary to the Rules of Decision Act. Because it is also quite possibly unconstitutional, the power to impose such burdens on state-created rights cannot be inferred from CJRA.

There is an analogy to contemporary developments in federal arbitration law having an adverse effect on the enforceability of state law, developinents that have likely sensitized the Court to the problem of federal obstructions to the enforcement of state law. In Southland Corporation v. Keating, ${ }^{351}$ the Court, in an excess of enthusiasm for arbitration, extended the 1925 Federal Arbitration Act to make it applicable in cases in state courts affecting interstate commerce. It also held that the Act preempted state laws invalidatimg arbitration clauses contained in contracts of adliesion that extended jurisdictions of arbitral tribunals to disputes arising in the private enforcement of state legislation. ${ }^{352}$ The Court had earlier reinterpreted the 1925 Act: For over four decades, it liad been a law bearing on the administration of the federal courts, but it became, without any utterance issuing from Congress, a law regulating interstate commerce. ${ }^{353}$ The further extensions of the Act in Southland weakened private enforcement of state law. This was not justified by the text or history of the federal act. It was also improvident and quite urmecessary to achieve any federal purpose that can be aligned with Article I. In 1994, twenty state attorneys general petitioned the Court to overrule Southland. ${ }^{354}$ The Court declined to do so, but with the majority sheepishly adimitting that Southland might well liave been wrong. The fundamental error of the Court in Southland was consistent with the degeneration of American courts as instruments of

350. Friends of the Earth v. Chevron Chemical Co., 885 F. Supp. 934, 939-40 (E.D. Texas 1995).

351. 465 U.S. 1 (1984).

352. Id. at 16.

353. Prima Paint Corp. v. Flood \& Conklin Mfg. Co., 388 U.S. 395 (1967). For an account of this development, see IAN R. MACNEIL, AMER1CAN ARBITRATION LAW: REFORMATION, NATIONALIZATION, INTERNATIONALIZATION 169-79 (1992).

354. Allied-Bruce Terminix Cos. v. Dobson, 115 S. Ct. 834, 838 (1995). 
law enforcement; the Court's error was that it attached so little importance to private law enforcement that it did not recognize the injury it was doing to the law of California; it was momentarily blind to the fact that arbitrators do not necessarily enforce legal rights and are not accountable for their failures to enforce them. If California, in the belief that law courts are more faithful to the law than arbitral tribunals, wants the rights it creates to be enforceable in court, there is no legitimate federal purpose achieved by preventing California from acting on that quite reasonable belief unless the California law in question conflicts with or is preempted by substantive federal legislation. If there is cost or delay associated with enforcement in court, the task of balancing those adverse consequences against the benefits of superior law enforcement is a political issue of the purest sort, and one that California is surely entitled, as a general matter, to make for itself. Likewise, if California or any other state disfavors a fee-shifting offer-of-settlement rule, it is no business of Congress to impose its different preference on cases involving enforcement of state-created rights when no substantive federal law is imperilled.

Insofar as the federal arbitration law is being applied to transactions in interstate commerce, Southland was merely wrong and not unconstitutional. And the Court has impliedly acknowledged that the federal arbitration law carmot be inade applicable to the litigation of state-created claims that involve disputes not affecting interstate commerce. ${ }^{355}$ That leaves the question of its application in a diversity case when the dispute is one not within reach of the commerce power. The Court has decided one sucl case; in the halcyon days of Erie, it held that a federal court nust in a case beyond the reach of the commerce power give effect to state law restricting the parties' power to make binding agreements to arbitrate future disputes. 356 That decision remains good law, resting as it does on a sound principle of constitutional federahisin. ${ }^{357} \mathrm{By}$ the same token, state law with respect to offers of settlement are

355. Id. at 839-41; cf. Perry v. Thomas, 482 U.S. 483, 491 (1987).

356. Bernhardt v. Polygraphic Co. of America, 350 U.S. 198 (1956).

357. For a case discussing Bernhardt, see Robert Lawrence Co. v. Devonshirc Fabrics, Inc., 271 F.2d 402, 404-05 (2d Cir. 1959), cert. dismissed, 364 U.S. 801 (1960). The court in Robert Lawrence presaged the holding of the Supreme Court in Prima Paint. It reinterpreted the 1925 Arbitration Act as an exercise of the commerce power in the belief that it would be unconstitutional to apply the act to actions in federal court merely on the basis of diversity jurisdiction. Id. at 404 . 
binding on federal courts, at least until Congress says otherwise in the exercise of one of its Article I powers.

The analogous, if lesser, effect of a fee-shifting offer of settlement rule on the worth of rights and defenses created by state law is demonstrated by comparing Friends of the Earth with Marek $v$. Chesny. Pursuant to the latter decision interpreting Rule 68 and the Civil Rights Act, the offer-of-settlement rule has fee-shifting effect only when Congress has so provided in legislation having an independent federal purpose linked to one of the enumerated Article I powers of Congress. To the extent that the Eastern Texas rule applies to cases in which Congress has voted to tax attorneys' fees as part of the "costs" awarded to a prevailing party under Rule 68, it is redundant. To the extent that the Plan might have been applicable to other disputes arising under federal law, the Plan would arm with an offer rule parties whoin, the Supreme Court inferred in Marek, Congress does not want so arned, either because it has made no provision for fee-shifting or because it has required fee shifting other than as part of the costs taxed under section 1920. If the Eastern Texas Plan were then read to be consistent with Marek's interpretation of the existing legislation, it has little or no application in suits to enforce federal law. ${ }^{358}$ It would be applied chiefly to induce settlement by parties in cases arising under state law. This would be a blatant affront to the constitutional principle expressed by Justices Field, Brandeis, and Holmes.

If and when Congress explicitly authorizes district courts to trump state law with "the law of the district," it will be time enough to decide whether it can do so. Meanwhile, it seeins clear that CJRA lias conferred no such authority on those who promulgate plans under that statute.

\section{CONCLUSION}

At the outset of this discussion of the applicable law, I raised six questions, a negative answer to any one of which was sufficient to invalidate the provisions of the Eastern Texas Plan under discussion here. My own behief, expressed here, is that the correct answers to each of the six questions are negative. Thus, the fee-

358. It is not clear that the Eastern Texas court means to be bound by Marek. One may infer from its opinion in Friends of the Earth that its Plan applies to federal cases brought for private benefit. 
shifting offer-of-settleinent rule set forth in the Eastern Texas Plan is not within the authority conferred by Congress on the district court. It violates Sections 1652, 1920, and 2071 of Title 28 of the United States Code. It is incidental that it also violates Federal Rules 68 and 83. Moreover, if Congress had purported to confer such power, its enactinent might well be three times unconstitutional. Friends of the Earth was therefore wrongly decided. The correction of that error will likely coine in time unless the Civil Justice Reform Act and its ninety-four plans expire before the issue is squarely presented to a court of appeals.

But that correction will be a nere skirmish in a larger struggle, the struggle to eusure the fidehty of our courts to law. In recent decades, nrany such skirmishes have been won by those who prefer that the law be not too rigorously applied to themselves and who are therefore attracted to governance by decrees ineasured to the length of each chancellor's foot. They have sometimes gained the support of soine judges seeking to inass-produce dispositions and other judges indulging idiosyncratic fancies such as the Eastern Texas Plan.

It is time to reverse the trend. An opportunity to do so will arise in 1997 when the reports on experience with the CJRA "experiments" are in. The Judicial Conference should take that occasion to sweep our national courts clear of all local clutter. A suggestion is that the Civil Rules, at least, should be revised to eliminate all authorizations for variations froin or elaborations or enhancements of the national rules, especially those promulgated in 1993 to accommodate CIRA.

David Culberson might have proposed that a local rule should be effective ouly if promulgated by the councils of the circuits upon a finding that it is recommended by the district judges and is responsive to a specified local need or serves a national need for controlled experimentation to be conducted under the auspices of the Federal Judicial Center. Each district judge would be permitted to issue standing orders, but in recoginition that such orders are clutter, they would not be permitted to exceed a length stipulated in the rules and should not be enforceable by any sanction prejudicing the substantive rights of hitigants. Congress, now as in the time of Culberson, should favor such restraints and should impose thein if the Judicial Conference proves reluctant to do so. Unrestrained localisin in the federal courts is mischief serving no purpose that Congress can honorably enibrace. 
If such action is taken, it may serve as a first step in restoring the professionalism of the federal courts. Whether it is or not, there will be other opportunities, other skirmishes, and other needs for correction. It is still true that in our republic, "law is king."359 Congressman Culberson, or his pohtical descendants, of whoin, the reader will have detected, I am one, will agam have our day, and we will keep our judges bound to their duties to ensure that the law is observed.

359. 1 The Complete Writings of Thomas PanNe 29 (Philip S. Foner ed. 1945). 


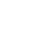

